\title{
Comparative performance study of different types of solar dryers for sustainability in agriculture applications
}

Melike Sultan Karasu Asnaz ( $\sim$ karasu@balikesir.edu.tr)

Balikesir University: Balikesir Universitesi https://orcid.org/0000-0003-4145-2524

\section{Ayse Ozdogan Dolcek}

Balikesir University: Balikesir Universitesi

\section{Research}

Keywords: Solar dryer, sustainable agriculture, dehumidifier, global sustainability

Posted Date: April 6th, 2021

DOI: https://doi.org/10.21203/rs.3.rs-365111/v1

License: (c) (i) This work is licensed under a Creative Commons Attribution 4.0 International License.

Read Full License

Version of Record: A version of this preprint was published at Energy Reports on November 1st, 2021. See the published version at https://doi.org/10.1016/j.egyr.2021.08.193. 


\title{
Comparative performance study of different types of solar dryers for sustainability in agriculture applications
}

\author{
Melike Sultan Karasu Asnaz ${ }^{\mathrm{a}^{*}}$, Ayse Ozdogan Dolcek ${ }^{\mathrm{b}}$ \\ ${ }^{a}$ Department of Industrial Engineering, Balikesir University, Balikesir, Turkey; ${ }^{b}$ Department of Geological \\ Engineering, Balikesir University, Balikesir, Turkey
}

Postharvest food loss increases rapidly every year in the world due to the inability to preserve food. Crop drying, which aims to reduce the moisture content to a certain level, is a method used to extend the shelf life of the food, and prevent it from spoiling. Solar drying is becoming a popular option to replace mechanical dryers due to the high cost of energy, and the increased awareness of consumer orientation to clean energy products.

In this study, three different low-cost solar dryers of natural convection dryer (NCD), forced convection dryer (FCD), and heat pump integrated solar dryer (HPD) were examined, and mushroom (agaricus bisporus) drying experiments were carried out on each. In this study, three main research topics were determined: (i) to analyse the drying characteristics of mushroom slices in different thicknesses $(0.5 \mathrm{~cm}, 1 \mathrm{~cm}$ and in half), (ii) to determine the effect of pretreatment on the drying time, (iii) to compare the collector efficiencies. For these purposes, 12 experiments were conducted between 9:00-18:00, the average daily solar irradiance was around $790 \mathrm{~W} / \mathrm{m}^{2}$. In 10 drying experiments out of 12 , it was observed that the samples were completely dried out within the experiment period, while the drying process of the half-cut mushrooms in NCD and FCD were completed after 18:00. The results show that cutting thin slices of mushrooms reduced the drying time by an average of 40.83 mins. Also, the process of pretreatment caused shorter drying time by an average of $26.66 \mathrm{mins}$, almost $7 \%$ in all cases. The average thermal efficiencies were found $59.74 \%, 67.66 \%$, and $77.45 \%$ for $\mathrm{NCD}, \mathrm{FCD}$ and $\mathrm{HPD}$, respectively. According to the results of this study, the most affecting factor in the overall drying process is found to be drying air which is hot and holds less moisture. In addition, it turned out that the drying rate increases with the increase of the temperature and speed of the drying air.

Keywords: Solar dryer, sustainable agriculture, dehumidifier, global sustainability

*corresponding author: karasu@balikesir.edu.tr 


\section{INTRODUCTION}

The main objectives of the agricultural production process are food security and sustainable agriculture. According to the 2030 Agenda for Sustainable Development, these goals can be achieved through sustainable farming practices and clean energy-based agriculture [1]. Current practice in agriculture in many countries around the world depends on fossil fuel-based power generation which causes and accelerates the climate change process due to greenhouse gas (GHG) emissions. In order to mitigate climate change and GHG emissions, there is a need for shifting existing finite fossil fuel power generation to renewable energy generation. Making this shift and increasing the use of renewable energy are the responsibilities of the entire sectors including agriculture industry.

According to Chel et al. [2], renewable resources have a huge potential for the agriculture industry. Promoting the adoption of solar, wind, geothermal and biomass applications into farming practices will not only maintain economic stability, but also minimize environmental impacts. The use of solar energy in agriculture industry is the most common practice with the largest variety. Low running costs, reliability and low maintenance are some of the advantages of solar applications. In general, solar energy can be utilized in two forms; one that converts solar energy into DC power such as solar water pump and solar water heater systems; and the other that converts solar heat radiations into heat such as greenhouse and solar food dryers.

Solar food dryers have been developed and used to dry agricultural products in order to preserve food and improve shelf life [3]. This type of dryers is also able to produce uncontaminated agricultural crop unlike open sun drying technique that usually result in contamination of the food by insects, dust, and mold. In order to obtain high quality dried products that will not threaten human health, hygienic conditions must be provided during drying process. Besides providing overall hygienic drying conditions, solar dryers have many advantages over open sun 
drying such as; reduced drying time, less spoilage, more uniform drying, and lets drying at low temperature, higher quality products in terms of color, texture and taste [4]. Appropriate methods should be investigated in order to maximize these advantages, and to maintain the sustainability of this technique.

Solar drying has been a subject of research for many years, it has been discussed in many scientific reports, research articles and books, and a limited research in the literature are presented in this section.

Drying methods using only solar energy have earlier been reviewed by Bolin et al. [5] in 1982. A wide variety of solar dryers, their designs, details of construction, basic principles and theories regarding the drying of agricultural food are reviewed comprehensively in [6]-[12]. Important findings on indirect type solar dryers for agricultural crops have been reviewed by Lingayat et al. [13], chemical pre-treatments, payback period and economic analysis were discussed in their paper. Purohit et al. [14] presented an economic analysis of solar drying and open sun drying, they developed a simple framework for the comparison of two applications. Later, Purohit et al. [15] studied techno-economic evaluation of solar crop dryers, and presented a framework for the financial assessment of an indirect type solar dryer replacing commercial fuels.

Mohanraj et al. [16] studied chili drying in a forced convection solar dryer with gravel as heat storage. They concluded that the inclusion of heat storage material increases the drying time by about 4 hours per day. Vijayan et al. [17] developed a forced convection solar dryer with a sensible heat storage, and presented its mathematical model and performance analysis in their study. According to their results, drying process in this dryer was more uniform as compared to open sun drying, and produced a higher quality product. 
Meisami et al. [18] studied the effects of drying air temperature and effects of slice thickness on the drying behavior of apple slices in a convective dryer. The experiment results showed that, increase of drying air temperature and decrease of slice thickness lead shorter drying times. Ziaforoughi et al. [19] designed and developed a solar assisted intermittent infrared dryer powered with a PV, and examined the drying parameters of different thicknesses of potato slices at temperatures of 50,60 and $70{ }^{\circ} \mathrm{C}$. Also, this study revealed a comparison between an intermittent infrared dryer and a solar assisted intermittent infrared dryer in terms of the amount of the energy consumption and the drying time.

The effect on quality of dried mushrooms in a medium size solar dryer was studied by Ashok et al. [20] for various chemical pretreatments of $1.0 \%$ potassium metabisulphite, $0.5 \%$ potassium metabisulphite, $0.5 \%$ citric acid, and $0.2 \%$ citric acid solutions, and applying $1 \%$ potassium metabisulphite gave best quality dried mushrooms. Different pre-treatments and different drying methods were also examined and compared by Kaur et al. [21] for drying of coriander leaves, and the best method was found to be dipping leaves for 15 minutes in solution of $0.1 \%$ magnesium chloride, $0.1 \%$ sodium bicarbonate and $2.0 \% \mathrm{KMS}$ at room temperature in a mini multi-rack solar dryer. El-Beltagy et al. [22] conducted experiments of drying strawberry slices in different shapes and pretreatment solutions in a forced solar dryer, and evaluated the quality attributes of dried strawberry slices. It was concluded that pretreatment and slicing reduced the drying time and did not affect the chemical composition of strawberry.

This study is mainly concerned with the effects of pretreatment applications prior to drying process, and the effects of different thickness of mushroom slices in different types of solar dryers. Drying experiments were carried out with mushrooms sliced in different thicknesses $(0.5 \mathrm{~cm}, 1 \mathrm{~cm}$ and half) in three different solar dryers (Natural Convection Dryer, Forced 
Convection Dryer and Heat Pump Solar Dryer). Weight loss, moisture content, drying rate and collector efficiencies were calculated, and the results were compared. In addition, $1 \mathrm{~cm}$ mushroom samples were soaked in $1 \%$ citric acid solution for ten minutes in order to monitor the drying characteristics of pretreated and non-pretreated products during drying activity.

With this purpose, Section 2 of the study will explain the details of dryers, data collection and theoretical background of drying process; $\underline{\text { Section } 3}$ presents the results of experiments, compares the performance of solar dryers, and discussed drying behaviours of mushrooms in different dryers; and finally conclusion is given in the last section.

\section{MATERIALS AND METHODS}

In this study, three different solar dryers with different features were used, and four mushroom drying experiments were carried out on each of them. These experiments were performed in city of Balikesir $\left(39.7^{\circ} \mathrm{N}, 27.9^{\circ} \mathrm{E}, 148 \mathrm{~m}\right.$ altitude) during summer season, between $10^{\text {th }}$ to $25^{\text {th }}$ of August 2020. The experiments were repeated for 15 days. However, three days with similar meteorological conditions were taken into account in order to reduce variations related to environmental conditions. All experiments started at 9:00 am, and finished at 6:00 pm. Solar dryer, which its collector inclined at $39^{\circ}$, was placed in the south.

Since the increased agricultural production need immediate drying for preservation[23], mushroom, a product with a short shelf life, was studied as a food to be dried in this study. Morphological changes occur in a short time from the harvest that prevent consumption, the preservation of the consumable mushroom in ambient conditions takes 10 days. [24]. Therefore, preserving mushrooms by drying, which lasts for 2-3 years, is one of the important preservation methods. Dried mushrooms can be used in a wide variety of foods such as soups and sauces. 
The variety of mushroom used in the experiments was cultivated mushroom (agaricus bisporus) produced by a local farmer. The initial moisture content was determined in an electrical drying oven and it was found to be \%91.68. In the literature [20], it is stated that there should be $5-8 \%$ moisture in dried mushrooms in terms of nutritional value and quality. All experiments were started with $50 \mathrm{~g}( \pm 0.5)$ of mushrooms and the experiments were terminated when the mass was observed to be $4 \mathrm{~g}( \pm 0.2)$.

\section{Details of Solar Dryers}

In this study, a single solar cabinet was manufactured and designed to be convertible into three different drying systems when required. The first of these is a natural convection dryer consisting of a with a single glass cover (glazed) solar collector $(80 \mathrm{cmx} 160 \mathrm{~cm})$, a drying chamber $(30 \mathrm{~cm} \times 70 \mathrm{~cm} x 80 \mathrm{~cm})$ and a chimney. $2 \mathrm{~mm}$ thick stainless steel was used to manufacture the dryer, a $60 \mathrm{~mm}$ thickness of glass wool was used to insulate the whole system, and painted matt black to maximize the absorption. This type of dryer allows the air enters from the bottom and passes through the collector and trays. Two fans operating with the power from a solar panel were added to this design and transformed into a Forced Convection Dryer. In the third, it was transformed into a solar assisted heat pump system that delivers dehumidified warm and dry air to the collector and drying chamber. The main purposes in the selection of these types of dryers are due to simple design, low maintenance and operating costs, and they are suitable for drying different products according to seasons. Details of designed and manufactured solar dryers are explained below, and pictured in Fig. 1. 


\section{Natural Convection Dryer}

As ambient air enters from the adjustable vents at the bottom and heats up in the solar collector, the warmed air will rise into the chamber where it extracts the moisture content from the food, and then exits through the chimney. Since no mechanical equipment is used to control the intake of air into the dryer, this system is also called a passive solar system and does not require any other energy during operation. Airflow in the collector or drying chamber is not controllable and constant, and it is mainly depend on wind speed and solar radiation [25]. Air flows are critical factors in natural circulation solar drying [26], thus designing a long solar chimney will provide a higher air flow which leads rapid rate of moisture removal from mushroom.

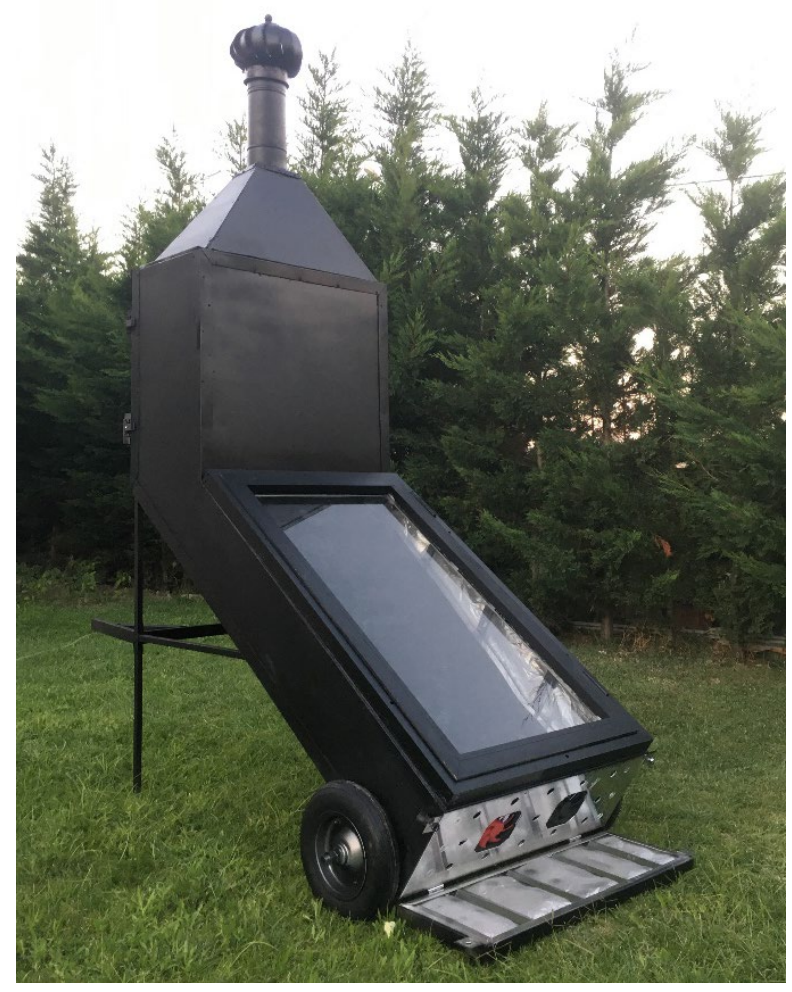

Figure 1. Solar Dryer 


\section{Forced Convection Dryer}

Factors such as ambient temperature and humidity, solar radiation, wind conditions, temperature and humidity inside the drying chamber, airflow, and density of foods are the parameters that affect the performance of a solar dryer. Since the change of one factor affects other factors, only the optimal values of these variables will give the best drying result. In this type of solar dryer, the temperature and the humidity inside the chamber can be regulated by controlling the airflow at the vents.

In this study, two DC fans $(24 \mathrm{~V}, 0.25 \mathrm{~A})$ powered by a $20 \mathrm{~W}$ solar panel are used to increase the airflow through the collector and the drying chamber. According to Hii et al. [27] this type of dryers performed well for drying higher moisture content food, like mushroom.

\section{Heat Pump Solar Dryer}

An air-to-air heat pump system which works like a dehumidifier is added to the dryer in order to remove the moisture from the air. In this system, a fan draws the ambient air through the evaporator which acts as a cooling element, and it constantly condenses the moisture in the air. Then the cool dry air is reheated by passing over a condenser which acts as a heating element, and fed the collector with hot and dry air which acts as the drying medium. The purpose of adding this mode to the design is to provide support when solar radiation is not sufficient during the day. Advantages of a solar collector designed with a heat pump are the continuity of the drying process, low energy consumption and resulted in high quality dried products [9]. Schematic diagram of this type of dryer is given in Fig. 2. 


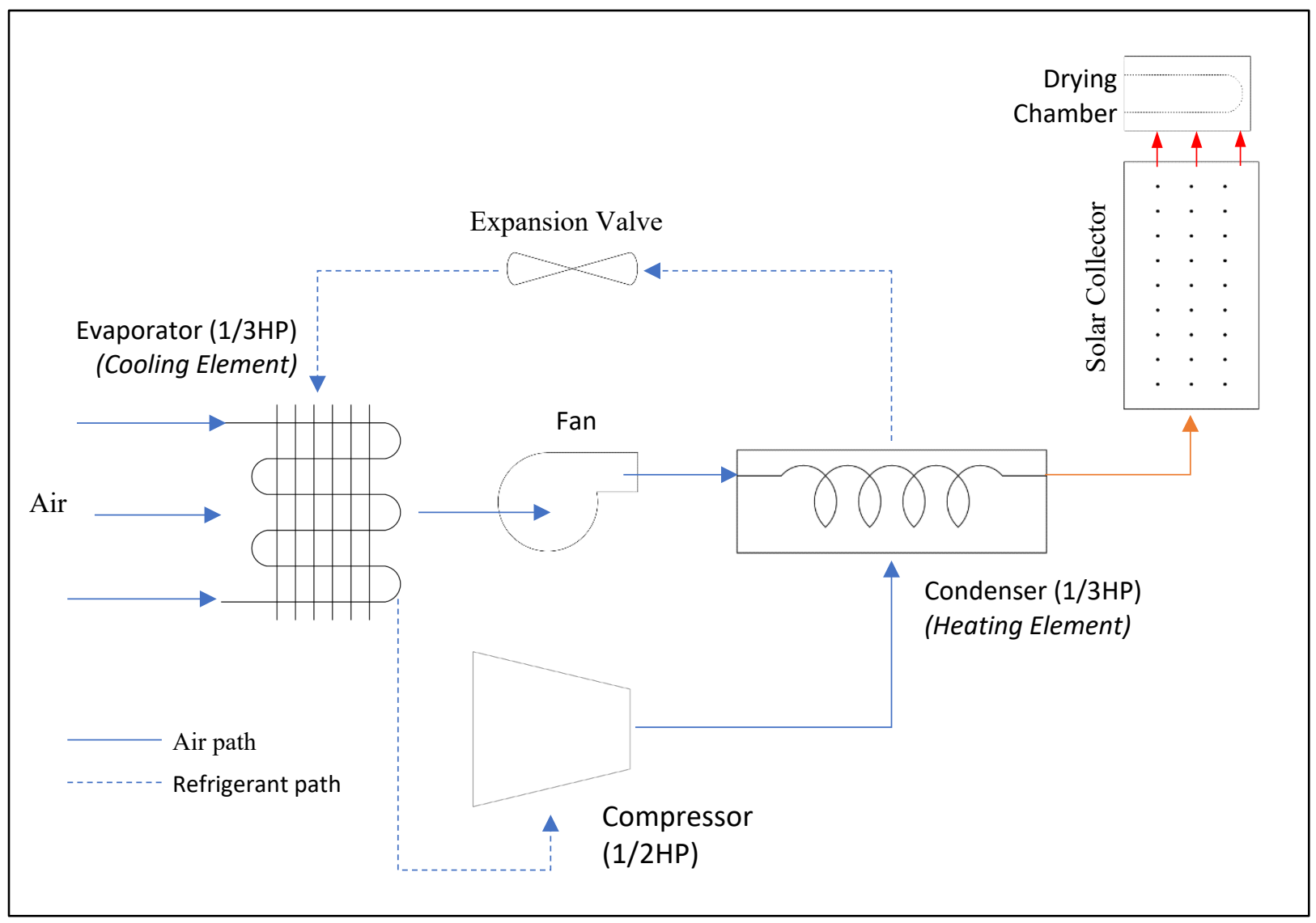

Figure 2. Schematic diagram of heat pump solar dryer

In this dryer, the moisture of the mushrooms in the drying chamber will evaporate with the heat from the solar collector and the condenser of the heat pump system. There are four main components in this heat pump solar dryer system: an expansion valve, a condenser $(1 / 3 \mathrm{HP})$, an evaporator (1/3 HP), a compressor (1/2 HP) that circulates the refrigerant (R134a) that absorbs and releases heat while traveling. Refrigerant is the heat transfer medium circulating between the components.

\section{Procedure}

In order to examine the effect of thickness on drying, the mushrooms were cut into halves, $0.5 \mathrm{~cm}$ and $1.0 \mathrm{~cm}$. In addition to thickness effect, the pre-treatment effect on drying rate was examined and for this, $1 \mathrm{~cm}$ thicken mushroom samples soaked in $1 \%$ citric acid solution for ten minutes at 
room temperature prior to drying. All samples were stuck in wooden sticks in order to maximize the evaporating surface area that exposed to dry air in the dryers. Mushrooms prepared for drying were cut vertically from middle portions and their surface areas were tried to be equal. The mean values of mass for each experiment are presented in Table 2 which also shows the summary of setups for all 12 experiments $\left(T_{1} \ldots T_{12}\right)$.

Table 1. Summary of experiments

\begin{tabular}{|l|l|l|l|l|}
\hline & $\begin{array}{l}0.5 \mathrm{~cm} \text { sliced } \\
\text { mushroom }- \text { no pre- } \\
\text { treatment }\end{array}$ & $\begin{array}{l}1 \mathrm{~cm} \text { sliced mushroom }- \\
\text { no pre-treatment }\end{array}$ & $\begin{array}{l}1 \mathrm{~cm} \text { sliced mushroom }- \\
\text { with pre-treatment } \\
\text { soaked in \%1 citric acid } \\
\text { solution for ten minutes) }\end{array}$ & Cut into halves \\
\hline Mean values of mass (gr.) & $3.3 \mathrm{gr}$ & $6.7 \mathrm{gr}$ & $6.8 \mathrm{gr}$ & $7.5 \mathrm{gr}$ \\
\hline $\begin{array}{l}\text { Natural Convection Dryer } \\
\text { (NCD) }\end{array}$ & $\mathrm{T} 1$ & $\mathrm{~T} 2$ & $\mathrm{~T} 3$ & $\mathrm{~T} 4$ \\
\hline $\begin{array}{l}\text { Forced Convection Dryer } \\
\text { (FCD) }\end{array}$ & $\mathrm{T} 5$ & $\mathrm{~T} 6$ & $\mathrm{~T} 7$ & $\mathrm{~T} 8$ \\
\hline $\begin{array}{l}\text { Heat Pump Solar Dryer } \\
\text { (HPD) }\end{array}$ & $\mathrm{T} 9$ & $\mathrm{~T} 10$ & $\mathrm{~T} 11$ & $\mathrm{~T} 12$ \\
\hline
\end{tabular}

\section{Data Collection}

The inside of the dryer and outside environment temperatures and relative humidity were measured with two temperature and two humidity sensors (DHT22 temperature and humidity sensor with the accuracy of $\pm 0.5^{\circ} \mathrm{C}$ and $\left.\pm \% 2.0 \mathrm{RH}\right)$. The sensors inside the dryer were positioned at the same level as where the first tray is placed. The other system that was used inside the dryer is a data logger (Testo $174 \mathrm{H}$ with the accuracy of $\pm 0.5^{\circ} \mathrm{C}$ and $\pm 3 \% \mathrm{rH}$ ) that records temperature and relative humidity data which was placed at the top of the dryer. Thus, inlet and outlet 
temperature and humidity data within the dryer was monitored. Drying air speed is monitored with a digital anemometer (Lutron YK-80AP with the accuracy of $\pm 2 \%+0.2 \mathrm{~m} / \mathrm{s}$ ).

Load cells (1 $\mathrm{kg}$ capacity with the accuracy of $0.0002 \mathrm{~kg}$ ) that were placed on top of the racks were used to monitor the change in weight of the food during drying process. The tray with the food on it was placed on the sensors and the sum of the data from the three sensors was taken. Then, the total weight of the food $\left(M_{t}\right)$ is obtained by subtracting the weight of the tray $\left(T_{m}\right)$ and wooden stick $\left(S_{m}\right)$ from this cumulative total, as shown in Eq. (1).

$$
M_{t}=M_{1}+M_{2}+M_{3}-T_{m}-S_{m}
$$

In the first phase of the experiments, the load cell sensors were placed in each corner of a tray and the samples weight was collected with a total of four sensors. However, in this process, it was observed that one side of the tray was lifted up, so the correct measurement was not taken. For this reason, three load cells placed on top of racks as a triangle shape, just like tripod legs, so that the trays were kept in balanced. The view of a tray placed on rack-mounted load cells is shown in the Fig. 3 below.
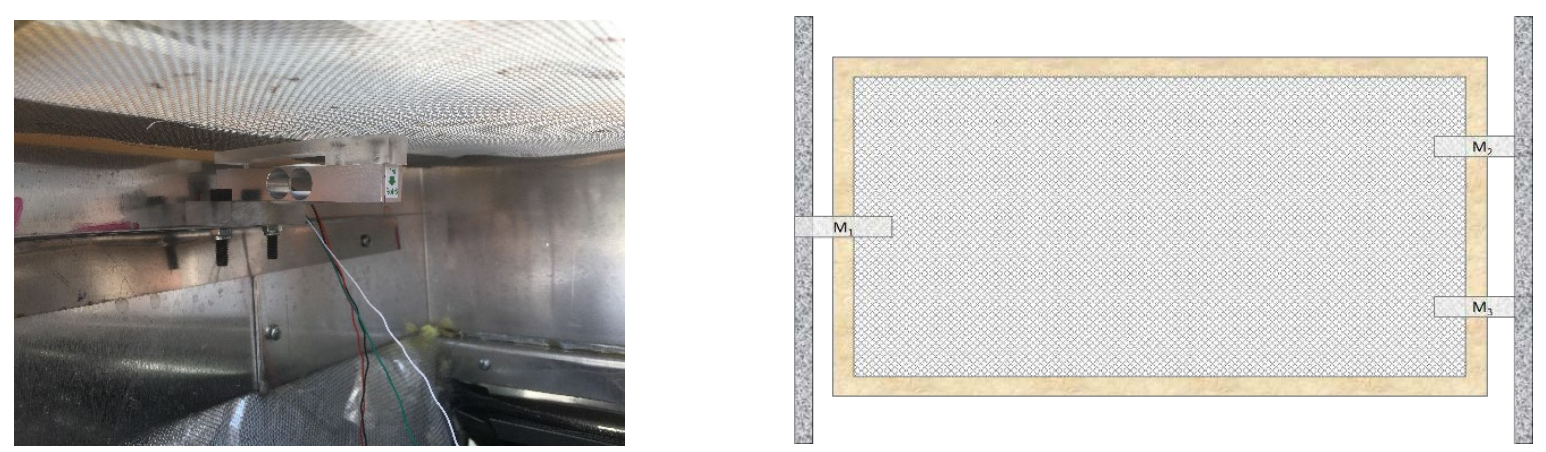

Figure 3. The placement of tray and load cells on a rack

A code was written with Arduino to instantly monitor the weight change of the food placed in three trays with the changes in temperature and relative humidity of the drying chamber and outdoor environment. These seven data can be monitored on the screen instantly, while 10-minute data is recorded throughout the experiments on an SD card. Food drying 
experiments in this study were performed with one tray placed at the bottom of the drying chamber.

Due to the errors and inaccuracies in the measuring devices used in the experiment, the measurement uncertainties should be calculated and kept as low as possible in order to reach the correct values of all parameters [28].

\section{Calculations}

Drying process is the application of heat to vaporize moisture which leads removing water from the food. Hence, heat transfer and mass transfer occur simultaneously in the drying procedure[27].

Drying curves were obtained for each sample depending on the time in the experiments. Dimensionless moisture content is calculated as in Eq. (2);

$$
M C=\left(M_{t}-M_{e}\right) \div\left(M_{o}-M_{e}\right)
$$

Here; MC represents the dimensionless moisture content, $M_{t}$ the mass of the mushroom in gram at any time on dry basis, $M_{e}$ the final mass of the dried mushroom, and $M_{0}$ the initial mass. The moisture content dry basis is calculated as;

$$
M C_{d r y \text { basis }}=\left(M_{t}-M_{e}\right) \div M_{e}
$$

Drying rate $(\%$ dry basis in $\mathrm{kg} / \mathrm{h})$ is the mass of moisture evaporated from mushroom per unit time, and is calculated using the Eq. (4);

$$
\text { Drying Rate }=\frac{d M}{d t}=\frac{M_{t+\Delta t}-M_{t}}{\Delta t}
$$

Thermal efficiency of the collector for NPD is calculated by dividing the useful heat gain by the solar radiation that arrives at the surface of the collector, as shown in Eq. (5)

$$
n_{C o l, N P D}=\frac{\dot{m}_{\text {air }} C_{p(\text { air })}\left(T_{\text {Col,outlet }}-T_{\text {Col,inlet }}\right)}{A_{\text {Col }} \times I} \times 100 \%
$$


Here, the thermal efficiency of the collector for NPD is $n_{C o l, N P D}$, the mass air-flow rate is $\dot{m}_{\text {air }}$ in $\mathrm{kg} / \mathrm{s}$, specific heat at constant pressure is $C_{p(\text { air })}$ in $\mathrm{kJ} / \mathrm{kg}^{\circ} \mathrm{C}$, the inlet and outlet temperature difference of solar collector is $\left(T_{\text {Col,outlet }}-T_{\text {Col,inlet }}\right)$ in ${ }^{\circ} \mathrm{C}$, surface area of collector is $A_{\text {Col }}$ in $\mathrm{m}^{2}$, and solar irradiation incident is $I \mathrm{in} \mathrm{W} / \mathrm{m}^{2}$.

$\dot{m}_{\text {air }}$ is calculated from $V \rho$, where $V$ is the volumetric flow rate in $\mathrm{m}^{3} / \mathrm{s}, \rho$ is the density of air in $\mathrm{kg} / \mathrm{m}^{3}$, and volumetric flow rate which is the volume of fluid which passes per unit time calculated by Eq. (6);

$$
V=v A_{c s}
$$

where $A_{c s}$ is cross-sectional area in $\mathrm{m}^{2}, v$ is the drying air speed in $\mathrm{m} / \mathrm{s}$.

The collector efficiency for FCD can be calculated as Eq. (7), where $P_{f}$ is the fan power.

$$
n_{C o l, F C D}=\frac{\dot{m}_{\text {air }} C_{p(\text { air })}\left(T_{\text {Col,outlet }}-T_{\text {Col,inlet }}\right)}{A_{\text {Col }} \times I+P_{f}} \times 100 \%
$$

For the performance of the HPD's collector, the coefficient of performance (COP) of the heat pump considering Carnot cycle is calculated by using the following equation, Eq. (8). The heat gain of the collector which represented in the numerator was calculated as in Eqs. (5) and (7). The denominator in the formula indicates the electricity consumption of the compressor, where $V$ is the voltage, $I$ is the current and $\cos \varphi$ is the power factor. The electricity consumed during the drying experiment was read from an electricity meter.

$$
\text { COP }=\frac{\left.\dot{m}_{\text {air }} C_{p(\text { air }}\right)\left(T_{\text {col,outlet }}-T_{\text {Col,inlet }}\right)}{V \times I \times \cos \varphi}
$$

Uncertainties are calculated through the root sum square method as explained in detail in Moffat's [29] paper. $\mathrm{R}$, calculated from a set of input data $\left(x_{1}, x_{2}, \ldots x_{n}\right)$, the uncertainty equation is shown in Eq. (9).

$$
\delta R=\left\{\left(\frac{\partial R}{\partial x_{1}} \delta x_{1}\right)^{2}+\left(\frac{\partial R}{\partial x_{2}} \delta x_{2}\right)^{2}+\cdots\left(\frac{\partial R}{\partial x_{n}} \delta x_{n}\right)^{2}\right\}^{1 / 2}
$$




\section{RESULTS AND DISCUSSION}

The results obtained from experiments performed on NCD, FCD and HPD dryers are discussed in this section. Changes of weight loss, moisture content, drying rates and collector efficiency were calculated, and their variations with temperature, humidity, solar radiation and drying rates are presented.

\section{Drying of mushroom in NCD}

This type of dryer entirely depends on solar energy for its drying operation. The heated air passes through the trays until the entire mushroom is dry. High drying air temperatures up to $70^{\circ} \mathrm{C}$ $100^{\circ} \mathrm{C}$ can be observed in this type of dryers, and these values are high enough to damage enzymes in most products [26]. In this experiment, the max. temperature inside the drying chamber reached $47.2^{\circ} \mathrm{C}$ while the ambient temperature was $35^{\circ} \mathrm{C}$ at $16: 00$.

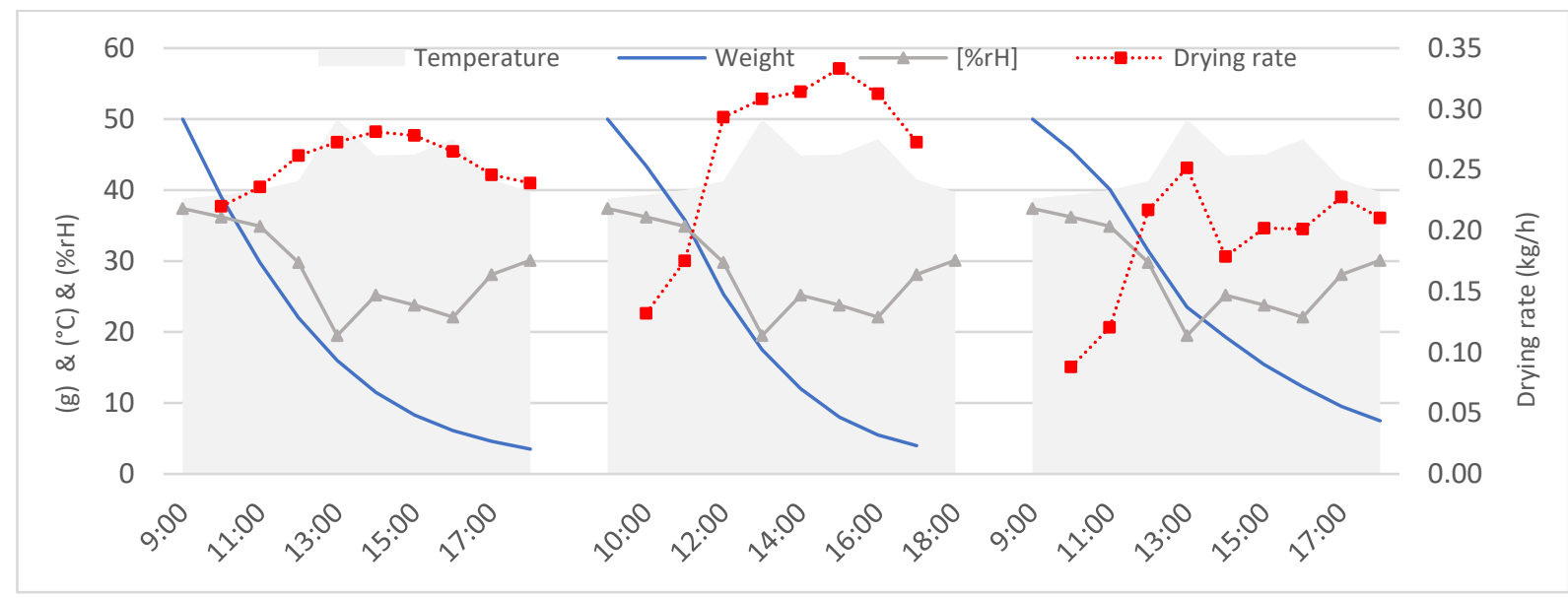

Figure 4. Relation between drying rate, temperature and relative humidity of drying chamber and drying time for $0.5 \mathrm{~cm}(\mathrm{~T} 1), 1 \mathrm{~cm}(\mathrm{~T} 2)$, and half (T4) sliced mushroom in NCD, respectively

Fig. 4 shows the drying parameters of $0.5 \mathrm{~cm}(\mathrm{~T} 1), 1 \mathrm{~cm}(\mathrm{~T} 2)$, and half (T4) sliced mushroom experiments, respectively. This graph shows the changes of weight of mushrooms, drying chamber temperature and the drying rate during the drying activity. Drying rate of mushroom represents the mass of moisture evaporated from mushroom per hour. The average 
drying rates $(\mathrm{kg} / \mathrm{h})$ were observed to be $0.27,0.26$ and 0.19 , respectively. The highest drying rates for all three samples were recorded at 15:00 when the min. relative humidity and the max. temperature reached at the chamber, as $0.28,0.33$ and 0.20 , respectively.

Fig. 5 shows the comparison of the parameters for pretreated $1 \mathrm{~cm}$ thick (T2) and nonpretreated $1 \mathrm{~cm}$ thick (T3) mushroom samples, respectively. According to Kumar et al.[11], the quality of dried product obtained by NCDs and the drying time can be improved by using pretreatment techniques. In the $\mathrm{T} 3$ experiment, samples were pretreated by soaking them in $1 \%$ citric acid solution for ten minutes prior to drying process. While the average drying rates were observed as 0.26 for $\mathrm{T} 2$, and 0.28 for $\mathrm{T} 3$; the pretreated $\mathrm{T} 3$ samples were completed the drying process between 16:00-17:00, and the non-pretreated $\mathrm{T} 2$ samples were dried approximately one hour later. So, the process of pretreatment achieved 13.1\% saving in drying time against nonpretreated drying.

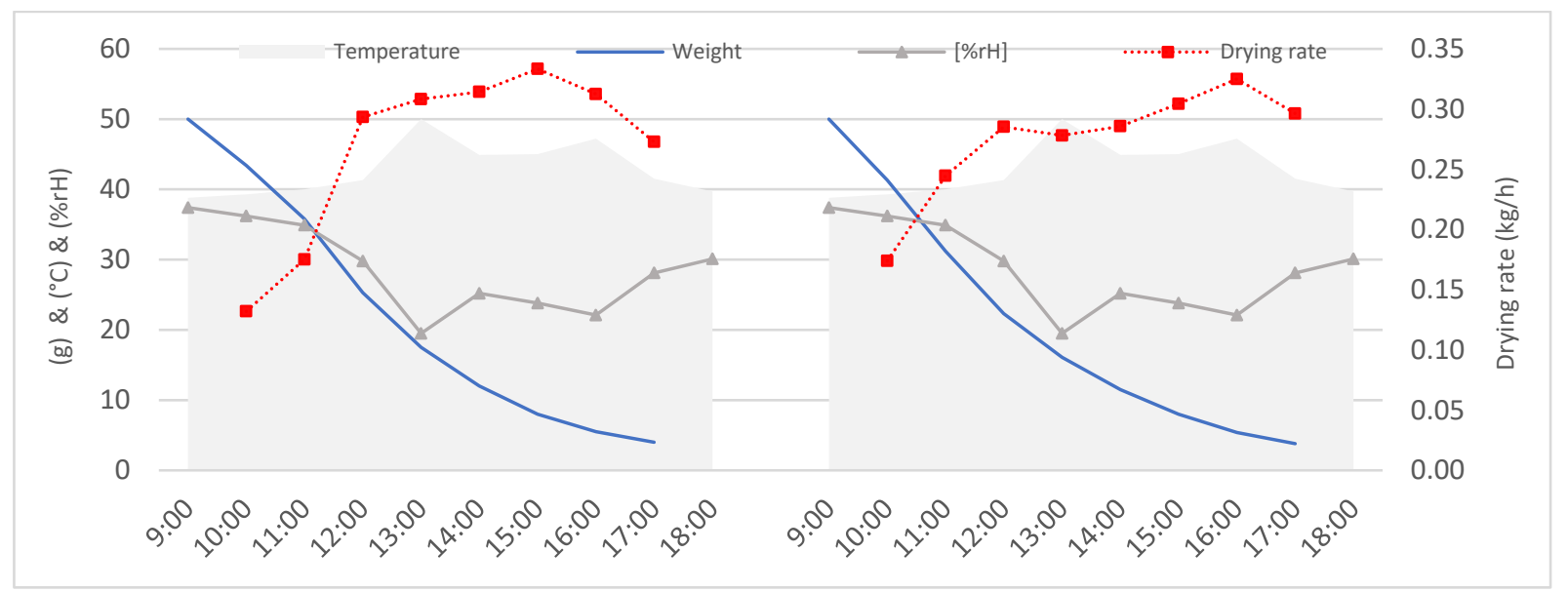

Figure 5. Relation between drying rate, temperature and relative humidity of drying chamber and drying time for non-pretreated (T2) and pretreated (T3) mushroom, respectively

In each experiment, it was seen that the drying rates are quite low in the first hours. The reason is that the solar intensity on the collector, and the temperature of the drying chamber are low in the mornings. It was observed that drying rate increases with temperature raise or 
moisture decrease in drying air, the max. drying rate occurred between 12:00-16:00 for all experiments.

\section{Drying of mushroom in FCD}

Vijayan et al. [17] stated that FCDs are more controllable and effective than NCDs, because of their high heat collection efficiency. In this experiment, the max. temperature inside the drying chamber reached $50.9^{\circ} \mathrm{C}$ while the ambient temperature was $35^{\circ} \mathrm{C}$ at $13: 00$, and the average temperature during the drying activity was $43.84^{\circ} \mathrm{C}$.

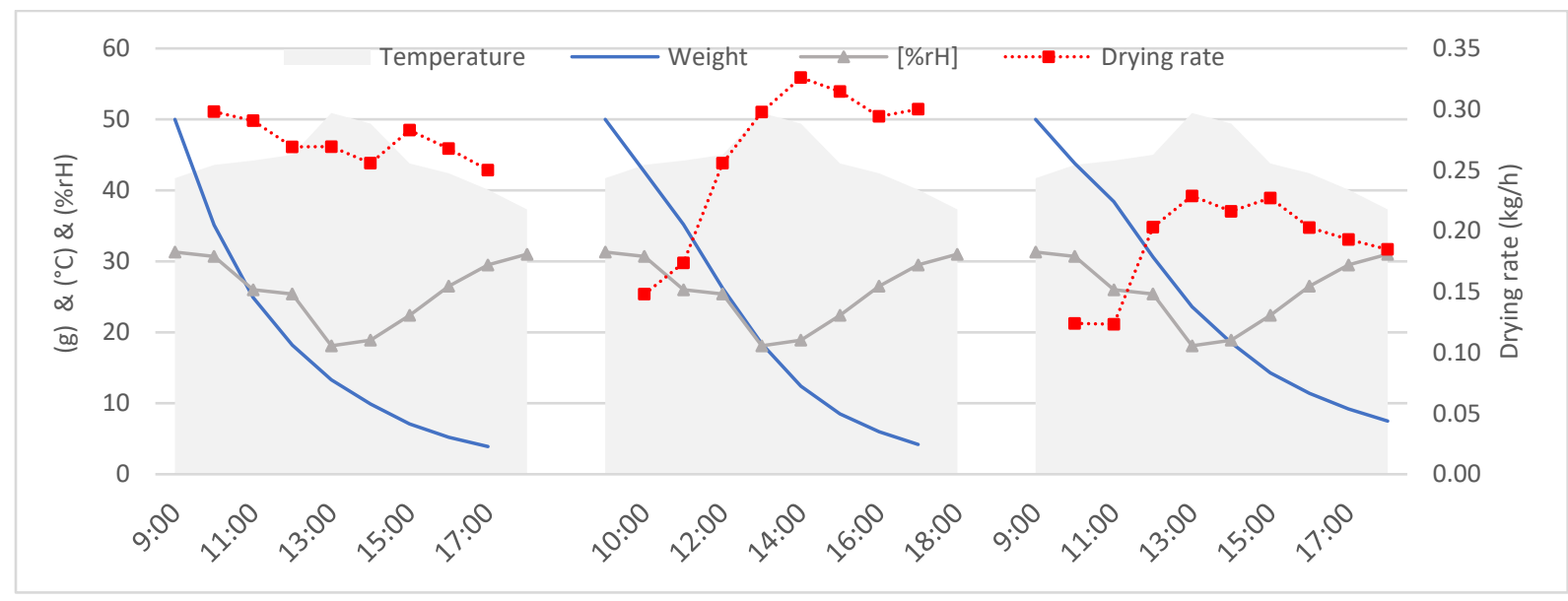

Figure 6. Relation between drying rate, temperature and relative humidity of drying chamber and drying time for $0.5 \mathrm{~cm}(\mathrm{~T} 5), 1 \mathrm{~cm}$ (T6), and half (T8) mushroom in FCD, respectively

Fig. 6 shows the $0.5 \mathrm{~cm}$ (T5), $1 \mathrm{~cm}$ (T6), and half (T8) sliced mushroom experiments conducted in FCD, respectively. Experiments were carried out between 9:00 and 18:00, and it was observed that the mushrooms divided into halves did not completely dried in both the NCD and the FCD systems. Besides, at the end of the experiments, it was observed that the samples sliced in $0.5 \mathrm{~cm}$ and $1 \mathrm{~cm}$ thickness were completely dried by 18:00. So, it was concluded that decreasing slice thickness caused shorter drying times, as Meisami-asl et al. [18] stated in their study. 
According to the experiments performed in FCD and NCD, the drying rates reached almost the same values. However, because of the increase in drying air velocity, the drying times of the samples reduced. For example, the $0.5 \mathrm{~cm}$ thickened mushroom sample completed the drying process in 510 minutes in NCD, and in 470 minutes in FCD, in other words $11.1 \%$ reduction in drying time was achieved. According to these experiments, it could be concluded that the main factors in the drying rate is both the drying air temperature and air velocity, as Gatea [30] revealed in his study.

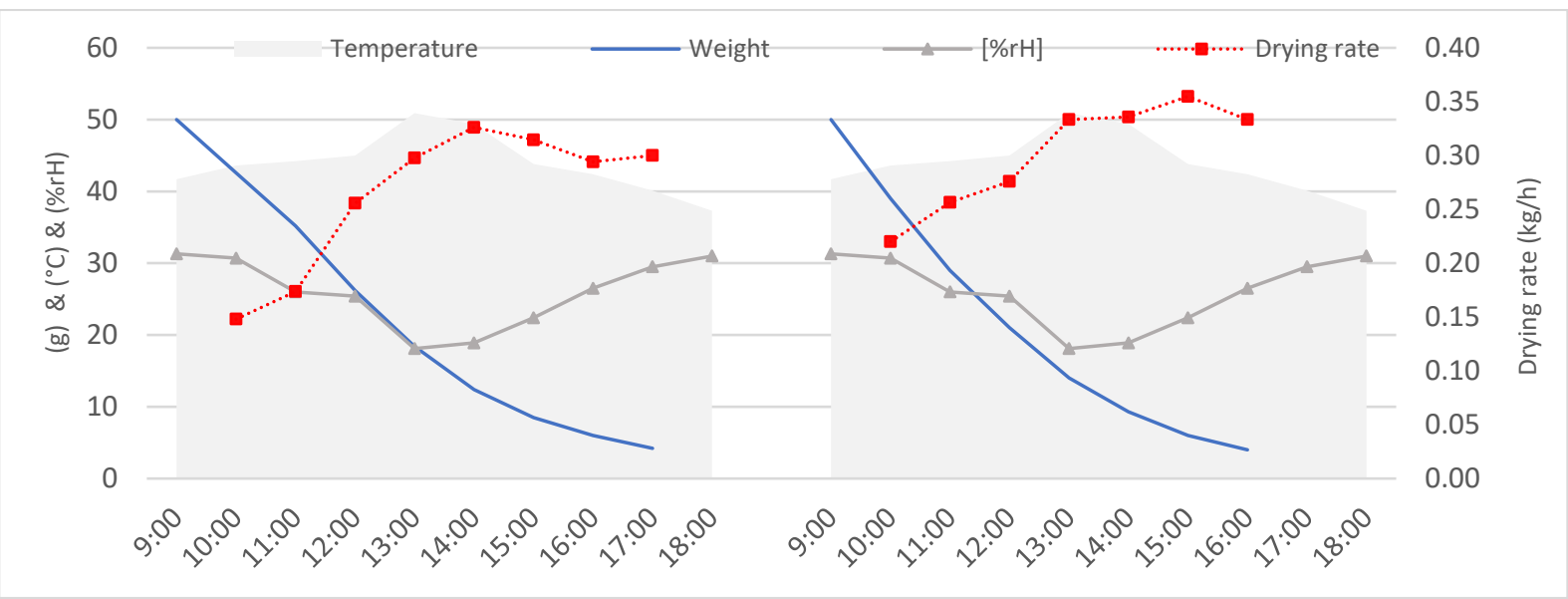

Figure 7. Relation between drying rate, temperature and relative humidity of drying chamber and drying time for non-pretreated (T6) and pre-treated (T7) mushroom, respectively

The comparison of the parameters of the pretreated(T6) and non-pretreated(T7) mushroom drying process in FCD are shown in Fig. 7, respectively. Drying rates were found to be 0.27 for $\mathrm{T} 6$, and 0.28 for $\mathrm{T} 7$ experiment. When the drying times of the samples were compared, T7 was completely dried 50 minutes before T6, so pretreatment provided an improvement of $10.10 \%$ on drying time. 


\section{Drying of mushroom in HPD}

The purpose of including a heat pump mode to the solar dryer is to be able to perform the drying process in cases where the solar radiation is insufficient during the day, regardless of the seasons and weather conditions. The components used in this drying system are shown in Fig. 2.

The HPD system not only provides uninterrupted hot drying air, but also cools the moist air in the evaporator and discharges the water inside. Thus, the drying air enters the condenser with reduced humidity, warms up with the work of the compressor and returns to the drying chamber.

During experiments it was observed that the average drying rates of $\mathrm{T} 9, \mathrm{~T} 10$ and $\mathrm{T} 12$ are $0.39,0.34,0.32$, respectively. The max. temperature in the dryer room was $53.6^{\circ} \mathrm{C}$ at $13: 00$, while the ambient temperature was $35.3^{\circ} \mathrm{C}$ and the collector temperature was $72.1^{\circ} \mathrm{C}$ at the same time.

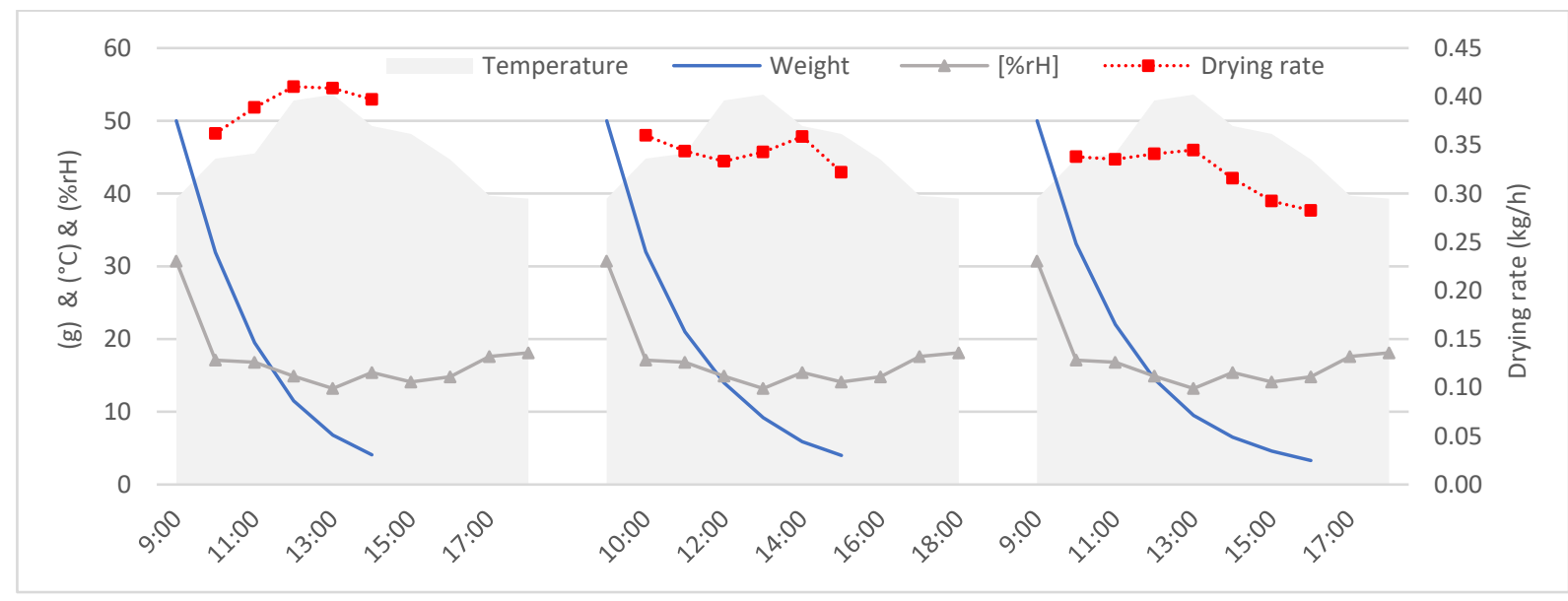

Figure 8. Relation between drying rate, temperature and relative humidity of drying chamber and drying time for $0.5 \mathrm{~cm}(\mathrm{~T} 9), 1 \mathrm{~cm}$ (T10), and half (T12) mushroom in HPD, respectively 


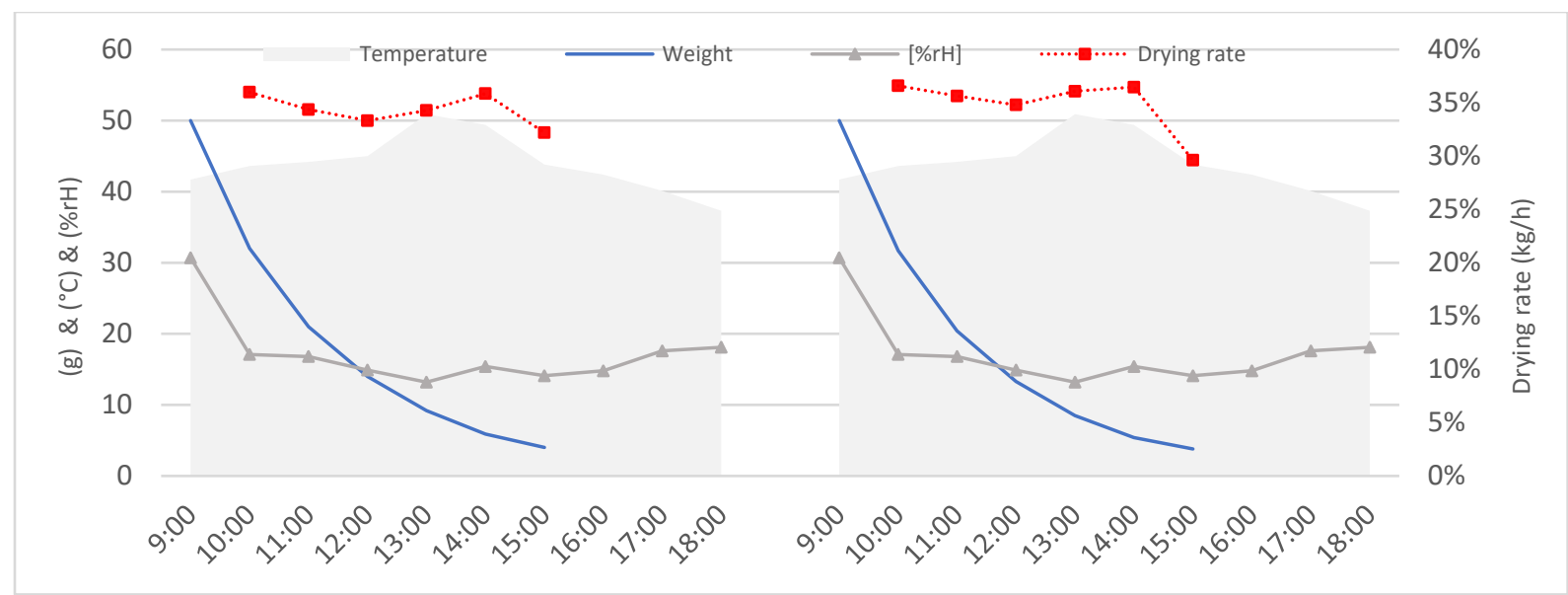

Figure 9. Relation between drying rate, temperature and relative humidity of drying chamber and drying time for non-pretreated (T10) and pre-treated (T11) mushroom, respectively

When the drying times of the pretreated sample and the non-pretreated sample were compared, it was observed that the pretreated sample dried faster, but the difference was negligible. The drying process of both ends before 15:30, when the interior of the collector reaches its max. temperature. Average drying rates were found to be 0.35 in both experiments, and a constant rate drying period was observed, as can be seen from Fig. 9. It can be concluded that the hot and low humidity drying air in the drying chamber provides higher drying rates, as.

As Weiss et al.’s [26] stated, the faster drying rate reduces the risk of spoilage by microorganisms and provides a higher throughput of food. The graphics above reflecting all these experiments and their results show that; drying the product in HPD is faster as it ensures that the heated air transported to the drying chamber is hot and at low humidity.

The amount of energy consumption was read from the electricity meter, and it was observed that there was an energy input of $20,428 \mathrm{~kW}$ into the system during the experiment period. According to Eq. (8), the COP value is obtained by dividing the heat load by the hourly power and the COP value for this system is found to be 4.07 . 


\section{Performance Comparison of all Dryers}

In order to compare the performances of collectors of solar dryers, twelve different experiments were evaluated with various drying parameters and remarks with their graphics are presented in this section. Experiments were carried out between 9:00 and 18:00 for fifteen days, and paired experiments were also conducted to determine the reproducibility of the results. The experimental results of the three days with the most similar meteorological characteristics were used for performance comparison.

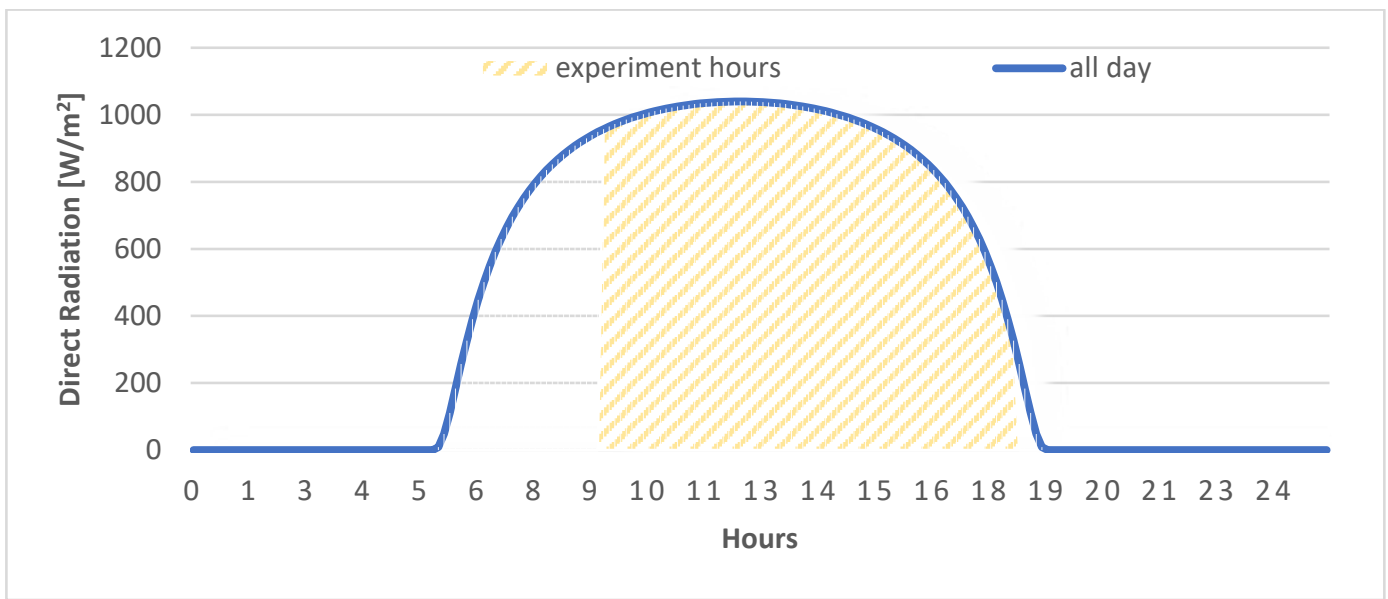

Figure 10. The intensity of direct radiation in $\mathrm{W} / \mathrm{m}^{2}$ throughout the day $\left(18^{\text {th }}\right.$ August 2020$)$ and experiment hours

As mentioned before, the experiments were carried out for fifteen days and three days with similar outdoor conditions were taken into account. Ambient temperature, relative humidity and wind velocity measurements for all three days were collected, and only one day's radiation values were taken into account since there is a negligible difference between the radiance values. Fig. 10 shows the hourly variation of solar radiation during the experiment day, with the max. of $1039.76 \mathrm{~W} / \mathrm{m}^{2}$ at $12: 00$, with an average of $790.11 \mathrm{~W} / \mathrm{m}^{2}$. 


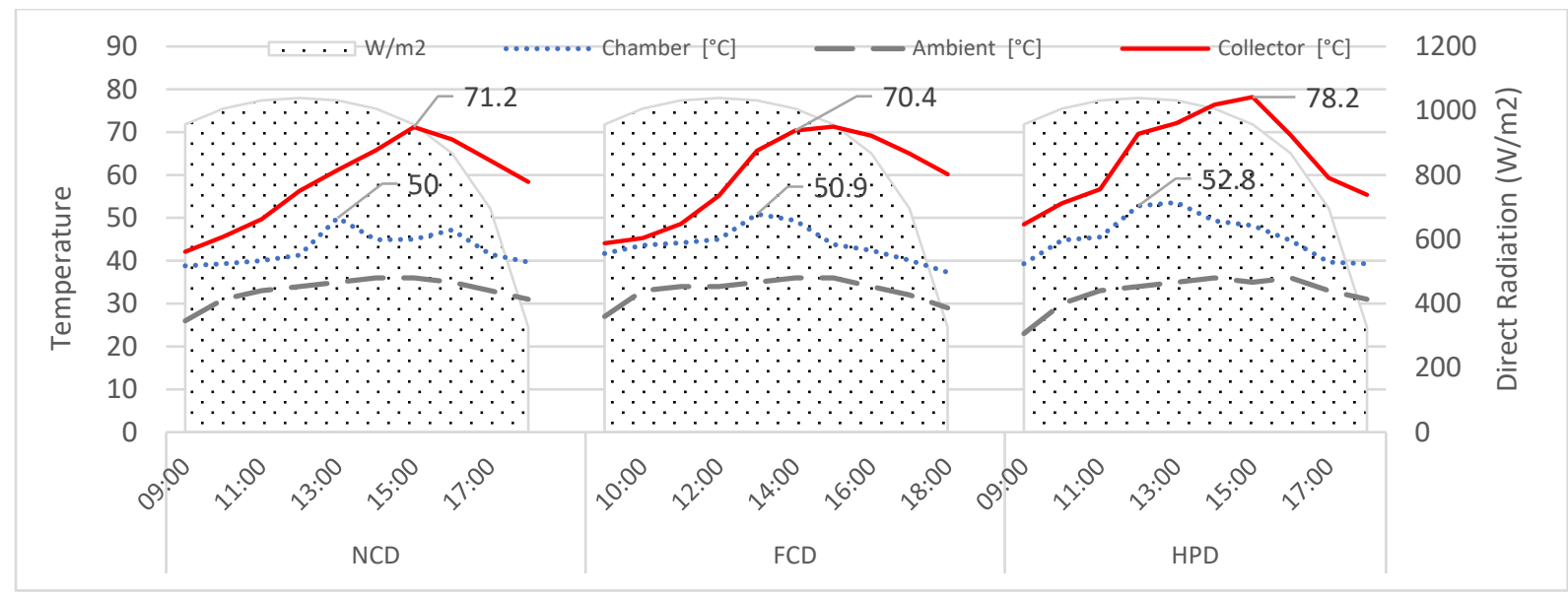

Figure 11 . The hourly variation of temperature and solar radiation for all dryers

The hourly variation of temperature and relative humidity values in all dryers are given in Fig. 11 and Fig. 12, respectively. According to Fig. 11, the temperature range inside the HPD chamber is higher than other dryers' chambers and ambient temperature during experiment hours. This shows the possibility that the HPD method will perform better than other dryers. In addition, according to the relative humidity graph in Fig. 12, the rapid drop in relative humidity in the HPD dryer chamber and its ability to keep it at a low level throughout the experiment can be interpreted as a sign that HPD will terminate the drying process faster.

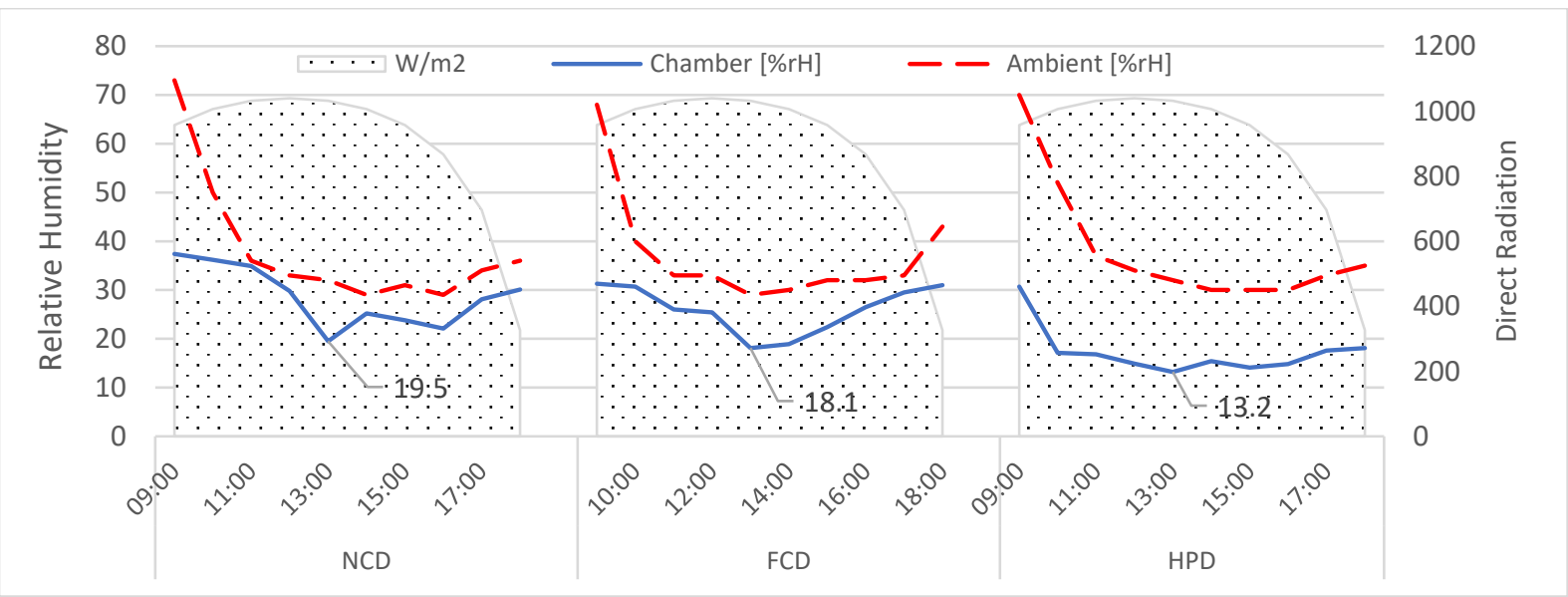

Figure 12 . The hourly variation of relative humidity and solar radiation for all dryers 
Table 2 shows the average values of various parameters measured on the days of the experiments.

Table 2. The average values of temperature relative humidity and solar radiation during the experimentations

\begin{tabular}{|l|l|l|l|}
\hline & NCD & FCD & HPD \\
\hline Experiment Day & $\begin{array}{l}224^{\text {th }} \text { Day }- \text { August } \\
12\end{array}$ & $\begin{array}{l}230^{\text {th }} \\
18\end{array}$ & $\begin{array}{l}233^{\text {rd }} \text { day }- \text { August } \\
21\end{array}$ \\
\hline Experiment Hours & $9: 00-18: 00$ & $9: 00-18: 00$ & $9: 00-18: 00$ \\
\hline Average Ambient Temperature $\left[{ }^{\circ} \mathrm{C}\right]$ & 33 & 33 & 32.6 \\
\hline Average Collector Temperature $\left[{ }^{\circ} \mathrm{C}\right]$ & 58.2 & 59.5 & 63.9 \\
\hline Average Chamber Temperature $\left[{ }^{\circ} \mathrm{C}\right]$ & 42.8 & 43.8 & 45.7 \\
\hline Average Chamber Relative Humidity $[\%]$ & 28.7 & 26.0 & 17.3 \\
\hline Average Ambient Relative Humidity $[\%]$ & 38.3 & 37.6 & 38.9 \\
\hline Average Solar Radiation $\left[\mathrm{W} / \mathrm{m}^{2}\right]$ & 790.12 & 790.06 & 790.14 \\
\hline Max. Solar Radiation $\left[\mathrm{W} / \mathrm{m}^{2}\right]$ & 1039.76 & 1039.64 & 1039.28 \\
\hline
\end{tabular}

\section{Drying behaviour of mushrooms in different dryers}

The drying curves for moisture content (\%dry basis) of same thickness samples in all types of dryers with respect to drying time and radiation is shown in Fig. 13. The initial moisture content of mushrooms dry basis was determined from Eq. (3) as an average of $11.50 \mathrm{~g}$ water/g dry matter. It is clear from the graph that as the thickness increased, the drying time increased in all dryers. In addition, the drying of samples of all thicknesses were completed first in HDP, then FCD, and finally in NCD. When analyzed in terms of drying times between NCD and FCD, it is seen that drying time was decreased by $13 \%$ by increasing air velocity in FCD. According to the authors [16], FCD is preferred over NCD because of its high heat collection efficiency and better controllability which provides more uniform drying. 


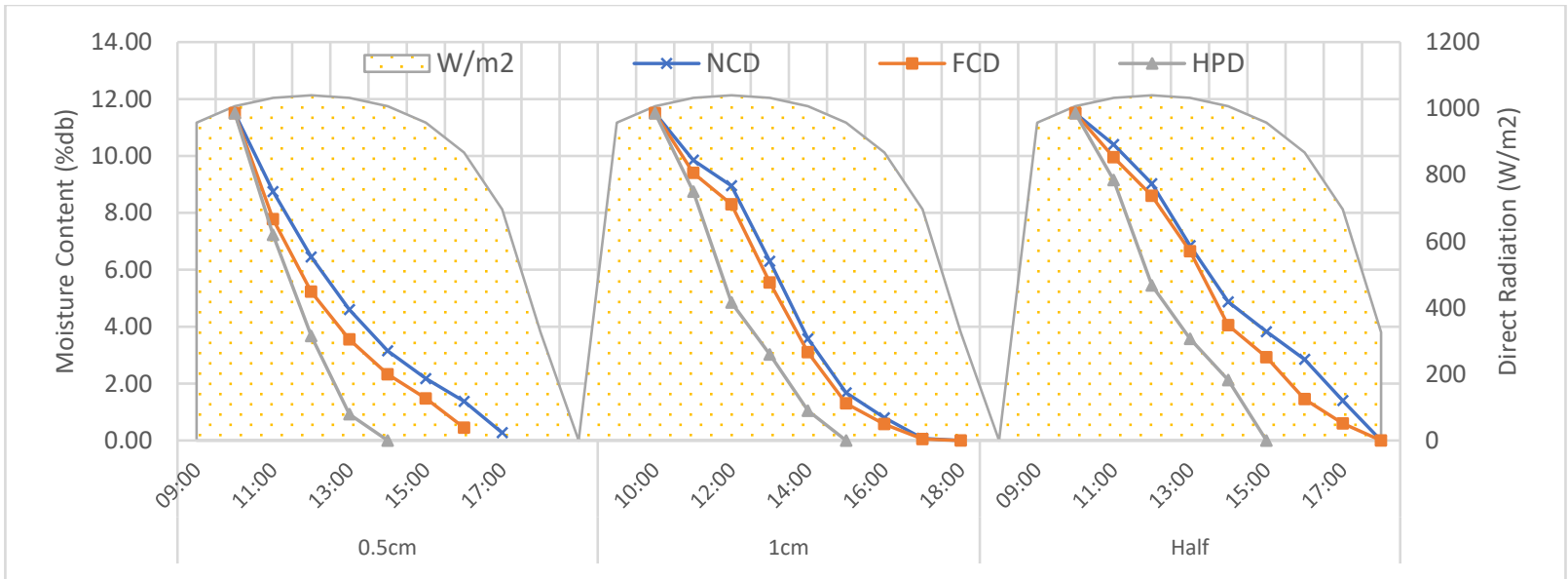

Figure 13. The variation of dry basis moisture content of mushroom in the NCD, FCD and HPD (T2, T6, and T10, respectively) with drying time in hours and direct radiation

The observed parameters during non-pretreated and pretreated drying experiments in all dryers were used to plot the drying curves, and shown in Fig. 14. In this figure, the drying tests (T2, T6, and T10) of $1 \mathrm{~cm}$ thick samples without pretreatment and the drying tests of the pretreated samples $(T 3, T 7$, and T11) are compared.

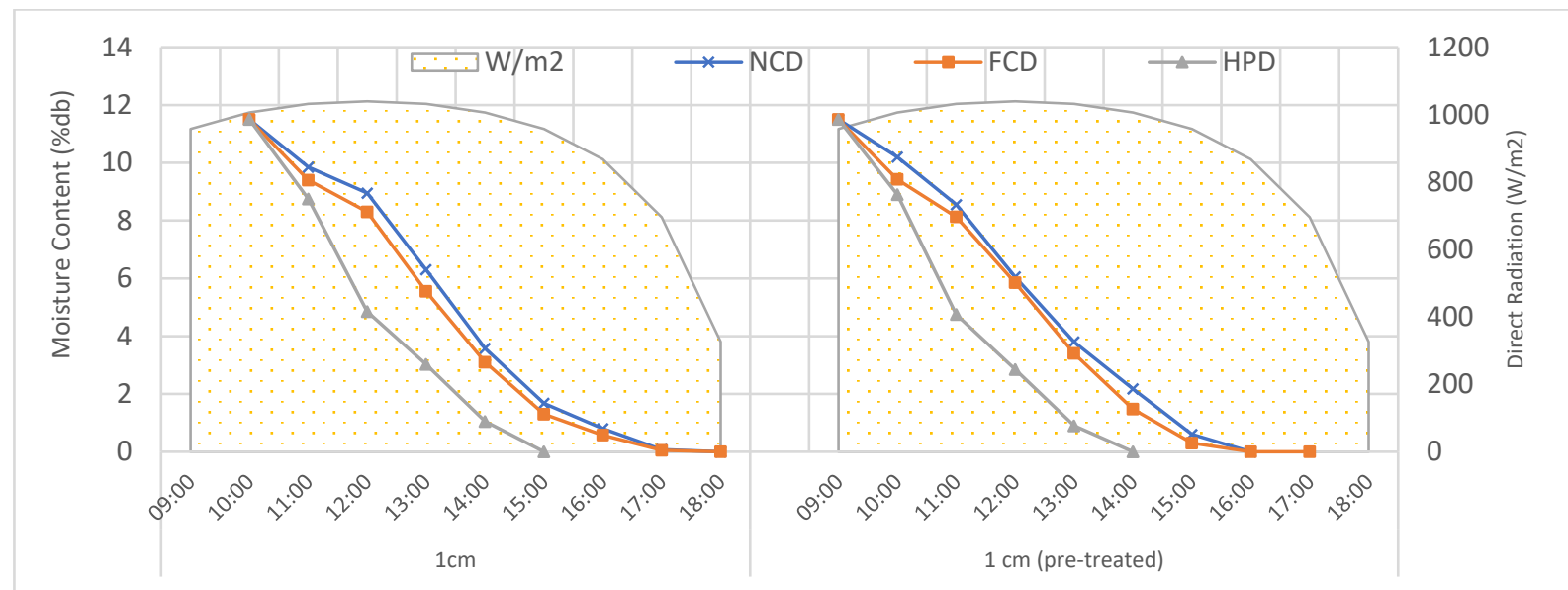

Figure 14. The variation of dry basis moisture content of mushroom in the NCD, FCD and HPD (T3, T7, and T11, respectively) with drying time in hours and direct radiation

While the drying process of all samples in both groups ends first in HPD, it can be observed that the drying times of all samples are almost same in FCD and NCD. Examining the 
effect of pretreatment on drying times, it was seen that drying times of all samples that were pretreated decreased by $7 \%$ to $13 \%$ compared to all samples that were not pretreated.

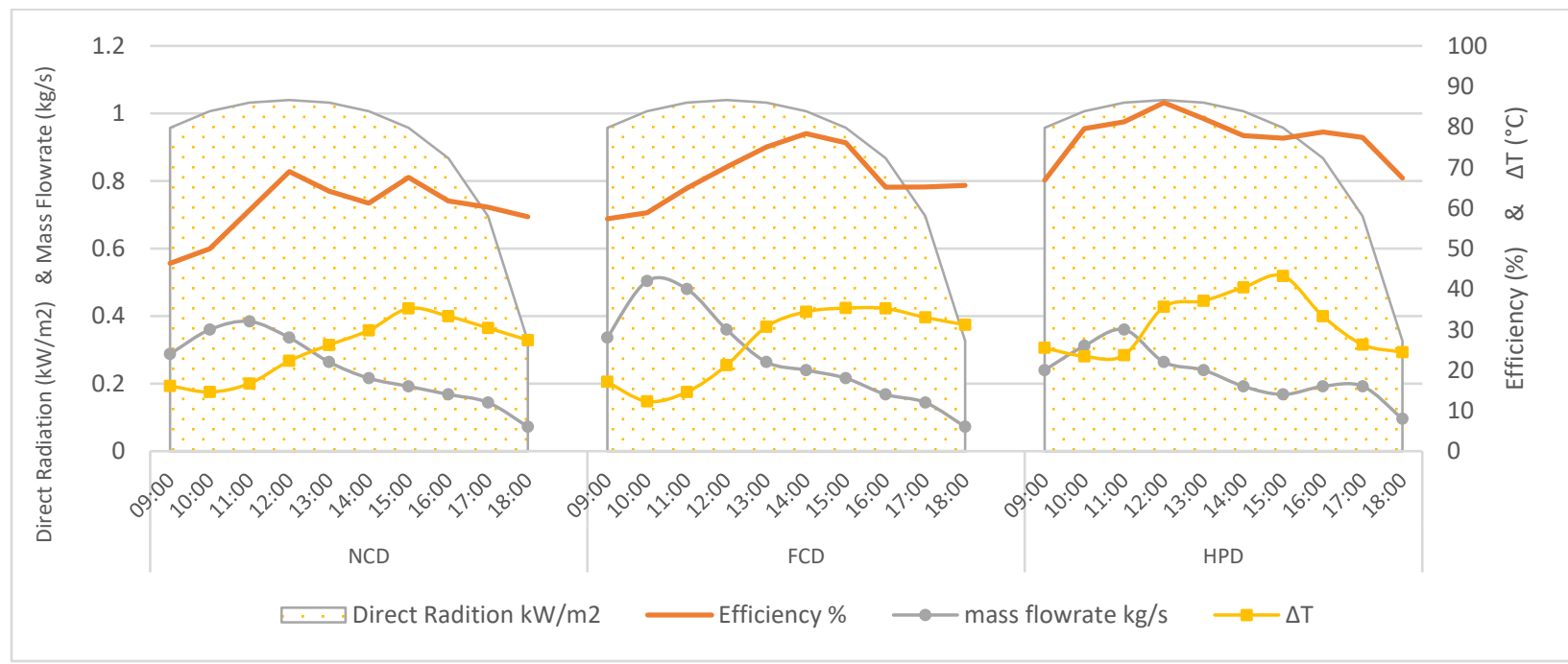

Figure 15. The efficiency of collectors for NCD, FCD and HPD with corresponding drying time and direct radiation

The efficiency of the solar collector depends on the volumetric air flow rate, inlet and outlet temperature difference $\left(T_{\text {Col,outlet }}-T_{\text {Col,inlet }}\right)$ and the intensity of solar radiation as in the Eq. (5) and Eq. (7). The efficiency for each collector was calculated, and the efficiency, mass flow rate and direct radiation variations during the drying period are shown in the graph as seen in Fig. 15. As Hawlader et al.'s [28] stated, the change of solar radiation affects the collector efficiency. It is observed that the efficiency of all types collectors increases as the collector absorbs more energy transferred to the air passing through the collector with the increase of solar radiation.

According to the experimental result, it was observed at the highest efficiency of the NCD solar collector the amount of $68.97 \%$ at $12: 00$, and the least efficient was obtained at 9:00 as $49.96 \%$. The highest efficiency observed in the FCD collector was $78.36 \%$ at $14: 00$, the lowest efficiency was observed as $57.34 \%$ at 9:00. Compared to the NCD collector, the average 
mass flow rate increased by $13 \%$ and efficiency increased by 7.92 with two DC fans used in FCD dryer to increase the volumetric air flow in the drying chamber. And finally, in the HPD collector which aimed to direct the dried hot air to the drying chamber, it is observed that the max. efficiency is $85.99 \%$ at $12: 00$ and the min. efficiency is $66.68 \%$ at $9: 00$. The average mass flow rate and average drying air speed values measured in HDP are similar to the NCD, but it is seen that the average efficiency is $17.71 \%$ higher than NCD, and $9.79 \%$ higher than FCD. A comparative summary table of the calculated average values in all dryers is given in Table $\mathbf{3}$.

Table 3. Comparison of different dryers based on average drying parameters

\begin{tabular}{lllllll}
\hline & NCD & & FCD & & HPD \\
\hline Av. Drying air speed & 1.01 & $\mathrm{~m} / \mathrm{s}$ & 1.16 & $\mathrm{~m} / \mathrm{s}$ & 1.07 & $\mathrm{~m} / \mathrm{s}$ \\
\hline Av. Mass flowrate & 0.30 & $\mathrm{~kg} / \mathrm{s}$ & 0.34 & $\mathrm{~kg} / \mathrm{s}$ & 0.30 & $\mathrm{~kg} / \mathrm{s}$ \\
\hline Av. Volumetric flowrate & 0.24 & $\mathrm{~m}^{3} / \mathrm{s}$ & 0.28 & $\mathrm{~m}^{3} / \mathrm{s}$ & 0.24 & $\mathrm{~m}^{3} / \mathrm{s}$ \\
\hline Av. Efficiency & 59.74 & $\%$ & 67.66 & $\%$ & 77.45 & $\%$
\end{tabular}

In this study, an uncertainty analysis has been made for collector efficiency. This value was estimated from the drying air speed, relative humidity, temperature and direct radiation measurements during the experiment and it was found to be approximately $\pm 2.5 \%$ based on Eq. (9).

\section{CONCLUSION}

Drying of food is needed to prevent food losses between harvest and consumption, and to ensure long term storage of food. The process of drying food using solar energy is one of the most common applications for food preservation. With the use of solar dryers that provide a hygienic and controllable environment for drying, the products can be dried quickly without being affected by seasonal variables, resulting in good quality dried products.

In this study there are three main objectives regarding solar drying process; to analyse (i) the effect of slicing of mushrooms, (ii) the effect of pretreatment of mushrooms prior to drying 
process, and (iii) the performance comparison of three type of solar dryers based on collector efficiencies. Paired experiments were also conducted to determine the repeatability of the results. In conclusion, the results clearly show that;

- It became clear that cutting thin slices of mushrooms reduced the drying time.

- It was found that the process of pretreatment reduced the drying time. According to the results of experiments, the drying process for the pretreatment experiments were terminated earlier with an average of $40 \mathrm{~min}$. comparing to non-pretreated experiments in NCD and FCD, while no significant difference was observed on drying times in HPD.

- It was observed that the drying rates were quite low in the first hours of the experiments due to the low solar radiation on the collector and insufficient drying chamber temperature. On the other hand, the max. drying rates were observed between 12:00 and 15:00, when the radiation was most intense.

- In NCD, where drying takes the longest, both average drying rate (0.26) and collector efficiency (59.74\%) were the lowest compared to other dryers. The drying rate is expected to be low as the NCD is insufficient to remove moist air. Therefore, better performance can be obtained in drying foods with low moisture content in this type of dryer. Airflow is a critical factor in solar drying; thus, NCD type dryers should be used especially in areas with relatively high average wind speed. Also, the only advantages of NCD over other dryers are low cost to manufacture, and simple maintenance.

- FCD drying experiments provided more uniform drying comparing to NCD. The addition of two fans to move the heated air from the collector area to the drying chamber increased the flow of air which made it easier to dehumidify the mushrooms. 
- Based on the experiments, the performance of the HPD system is promising, showing an average efficiency of $77.45 \%$. Using an air-source heat pump as a dehumidifier significantly shortened the drying time. However, the initial cost of this type of systems is higher than NCD and FCD.

- It was found that the most affecting factor in the overall drying process is that hot and low moist drying air. In addition, it turned out that the drying rate increases with the increase of the temperature and speed of the drying air.

- When the drying rate and efficiency graphs are examined, it is seen that these values are low at the beginning, and increased over time. This is due to the fact that the drying energy demand is high at the beginning and decreases towards the end, which means that time is needed for the collectors to heat up.

\section{Data availability}

The datasets used and/or analysed during the current study are available from the corresponding author on reasonable request.

\section{Competing interests}

The authors declare that they have no competing interests.

\section{Funding}

This work was financially supported by Scientific Research Coordination Unit of Balikesir University under the project number BAP.2019/08.

\section{Authors' contributions}

MSKA designed the dryer, conceived and designed the experiments, performed the calculations and the analysis. AOD contributed data and performed the analysis.

\section{Acknowledgments}

Not applicable.

\section{REFERENCES}

[1] UN General Assembly, "UN General Assembly, Transforming our world : the 2030 Agenda for Sustainable Development, 21 October 2015, A/RES/70/1, available at: 
https://www.refworld.org/docid/57b6e3e44.html [accessed 28 November 2019]," vol. 16301, no. October, pp. 1-35, 2015.

[2] A. Chel and G. Kaushik, "Renewable energy for sustainable agriculture," Agron. Sustain. Dev., vol. 31, no. 1, pp. 91-118, 2011.

[3] R. V. S. Raju, R. M. Reddy, and E. S. Reddy, "Design and Fabrication of Efficient Solar Dryer,” J. Eng. Res. Appl., vol. 3, no. 6, pp. 1445-1458, 2013.

[4] A. Esper and W. Mühlbauer, "Solar drying - An effective means of food preservation," Renew. Energy, vol. 15, no. 1-4, pp. 95-100, 1998.

[5] H. R. Bolin and D. K. Salunkhe, "Food dehydration by solar energy," C R C Crit. Rev. Food Sci. Nutr., vol. 16, no. 4, pp. 327-354, 1982.

[6] O. V. Ekechukwu, "Review of solar-energy drying systems I: An overview of drying principles and theory," Energy Convers. Manag., vol. 40, no. 6, pp. 593-613, 1999.

[7] O. V Ekechukwu and B. Norton, "Review of solar-energy drying systems II: an overview of solar drying technology," Energy Convers. Manag., vol. 40, no. 6, pp. 615-655, 1999.

[8] O. V Ekechukwu and B. Norton, "Review of solar-energy drying systems III: low temperature air-heating solar collectors for crop drying applications," Energy Convers. Manag., vol. 40, no. 6, pp. 657-667, 1999.

[9] A. Fudholi, K. Sopian, M. H. Ruslan, M. A. Alghoul, and M. Y. Sulaiman, "Review of solar dryers for agricultural and marine products," Renew. Sustain. Energy Rev., vol. 14, no. 1, pp. 1-30, 2010.

[10] S. Vijayavenkataraman, S. Iniyan, and R. Goic, "A review of solar drying technologies," Renew. Sustain. Energy Rev., vol. 16, no. 5, pp. 2652-2670, 2012.

[11] M. Kumar, S. K. Sansaniwal, and P. Khatak, "Progress in solar dryers for drying various commodities," Renew. Sustain. Energy Rev., vol. 55, pp. 346-360, 2016.

[12] A. Fudholi and K. Sopian, "A review of solar air flat plate collector for drying application," Renew. Sustain. Energy Rev., vol. 102, no. December 2018, pp. 333-345, 2019.

[13] A. B. Lingayat, V. P. Chandramohan, V. R. K. Raju, and V. Meda, "A review on indirect type solar dryers for agricultural crops - Dryer setup, its performance, energy storage and important highlights," Appl. Energy, vol. 258, no. May 2019, p. 114005, 2020. 
[14] P. Purohit, A. Kumar, and T. C. Kandpal, "Solar drying vs. open sun drying: A framework for financial evaluation," Sol. Energy, vol. 80, no. 12, pp. 1568-1579, 2006.

[15] P. Purohit and T. C. Kandpal, "Solar crop dryer for saving commercial fuels: A technoeconomic evaluation," Int. J. Ambient Energy, vol. 26, no. 1, pp. 3-12, 2005.

[16] M. Mohanraj and P. Chandrasekar, "Performance of a forced convection solar drier integrated with gravel as heat storage material," Proc. IASTED Int. Conf. Sol. Energy, SOE 2009, no. September, pp. 51-54, 2009.

[17] S. Vijayan, T. V. Arjunan, and A. Kumar, "Mathematical modeling and performance analysis of thin layer drying of bitter gourd in sensible storage based indirect solar dryer," Innov. Food Sci. Emerg. Technol., vol. 36, pp. 59-67, 2016.

[18] E. Meisami-asl, S. Rafiee, A. Keyhani, and A. Tabatabaeefar, "Determination of suitable thin layer drying curve model for apple slices (variety-Golab)," Plant Omics, vol. 3, no. 3, pp. 103-108, 2010.

[19] A. Ziaforoughi and J. A. Esfahani, "A salient reduction of energy consumption and drying time in a novel PV-solar collector-assisted intermittent infrared dryer," Sol. Energy, vol. 136, pp. 428-436, 2016.

[20] A. Kumar, M. Singh, and G. Singh, "Effect of different pretreatments on the quality of mushrooms during solar drying," J. Food Sci. Technol., vol. 50, no. 1, pp. 165-170, 2013.

[21] P. Kaur, A. Kumar, S. Arora, and B. S. Ghuman, "Quality of dried coriander leaves as affected by pretreatments and method of drying," Eur. Food Res. Technol., vol. 223, no. 2, pp. 189-194, 2006.

[22] A. El-Beltagy, G. R. Gamea, and A. H. A. Essa, "Solar drying characteristics of strawberry," J. Food Eng., vol. 78, no. 2, pp. 456-464, 2007.

[23] V. Belessiotis and E. Delyannis, "Solar drying," Sol. Energy, vol. 85, no. 8, pp. 1665$1691,2011$.

[24] S. K. Giri and S. Prasad, "Quality and moisture sorption characteristics of microwavevacuum, air and freeze-dried button mushroom (agaricus bisporus)," J. Food Process. Preserv., vol. 33, no. SUPPL. 1, pp. 237-251, 2009. 
[25] D. R. Pangavhane, R. L. Sawhney, and P. N. Sarsavadia, "Design, development and performance testing of a new natural convection solar dryer," Energy, vol. 27, no. 6, pp. 579-590, 2002.

[26] W. Weiss and J. Buchinger, "Establishment of a production, sales and consulting infrastructure for solar thermal plants in Zimbabwe," Inst. Sustain. Technol., p. 110, 2004.

[27] A. S. Hii, Ching Lik; Jangam, Scahin Vinayak; Ong Sze Pheng; Mujumdar, Solar Drying: Fundamentals, Applications and Innovations. Singapur, 2012.

[28] M. N. A. Hawlader, S. M. A. Rahman, and K. A. Jahangeer, "Performance of evaporatorcollector and air collector in solar assisted heat pump dryer," Energy Convers. Manag., vol. 49, no. 6, pp. 1612-1619, 2008.

[29] R. J. Moffat, "Using uncertainty analysis in the planning of an experiment," J. Fluids Eng. Trans. ASME, vol. 107, no. 2, pp. 173-178, 1985.

[30] A. A. Gatea, "Performance evaluation of a mixed-mode solar dryer for evaporating moisture in beans," J. Agric. Biotechnol. Sustain. Dev., vol. 3, no. April, pp. 65-71, 2011. 
Figures

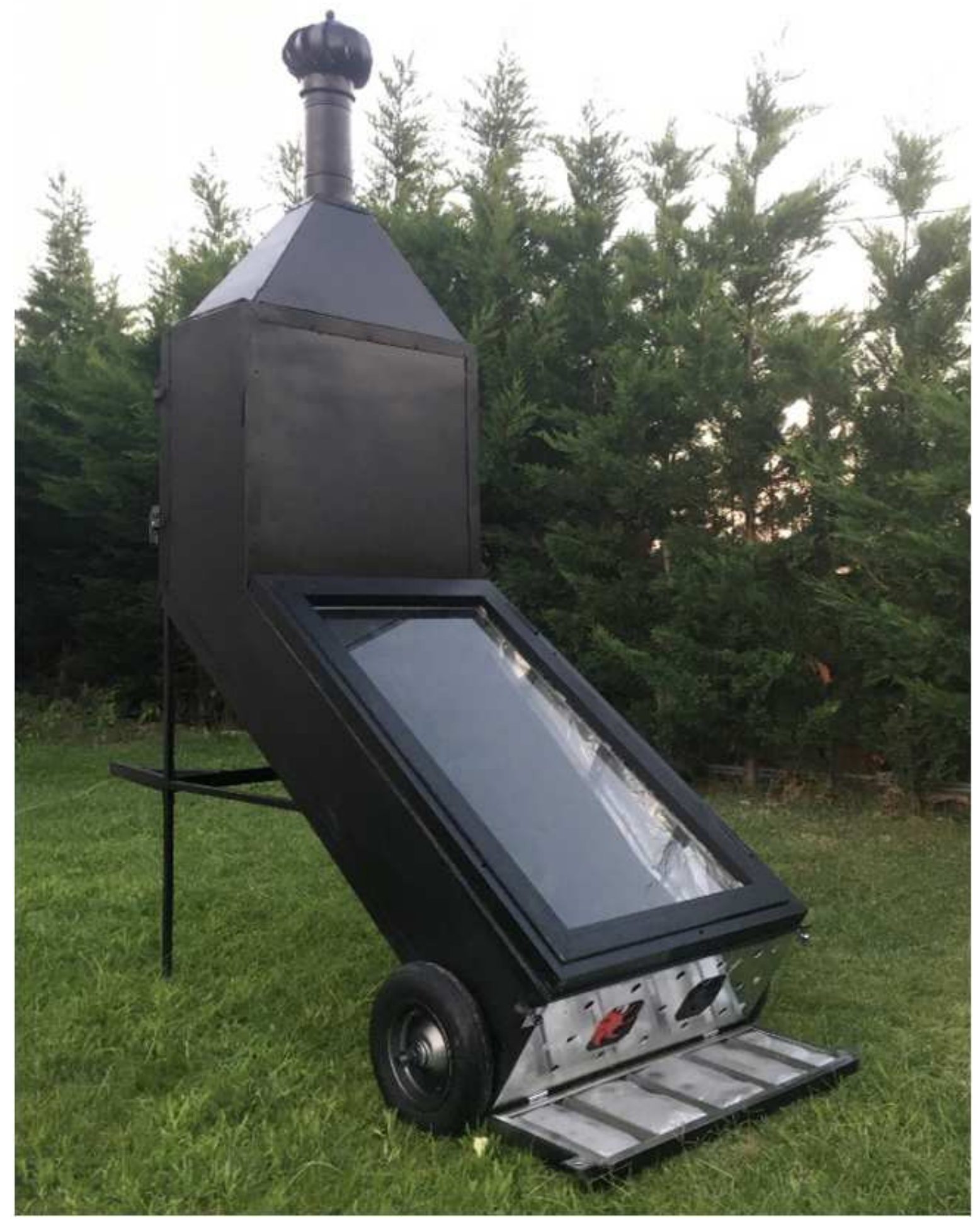

Figure 1

Solar Dryer 


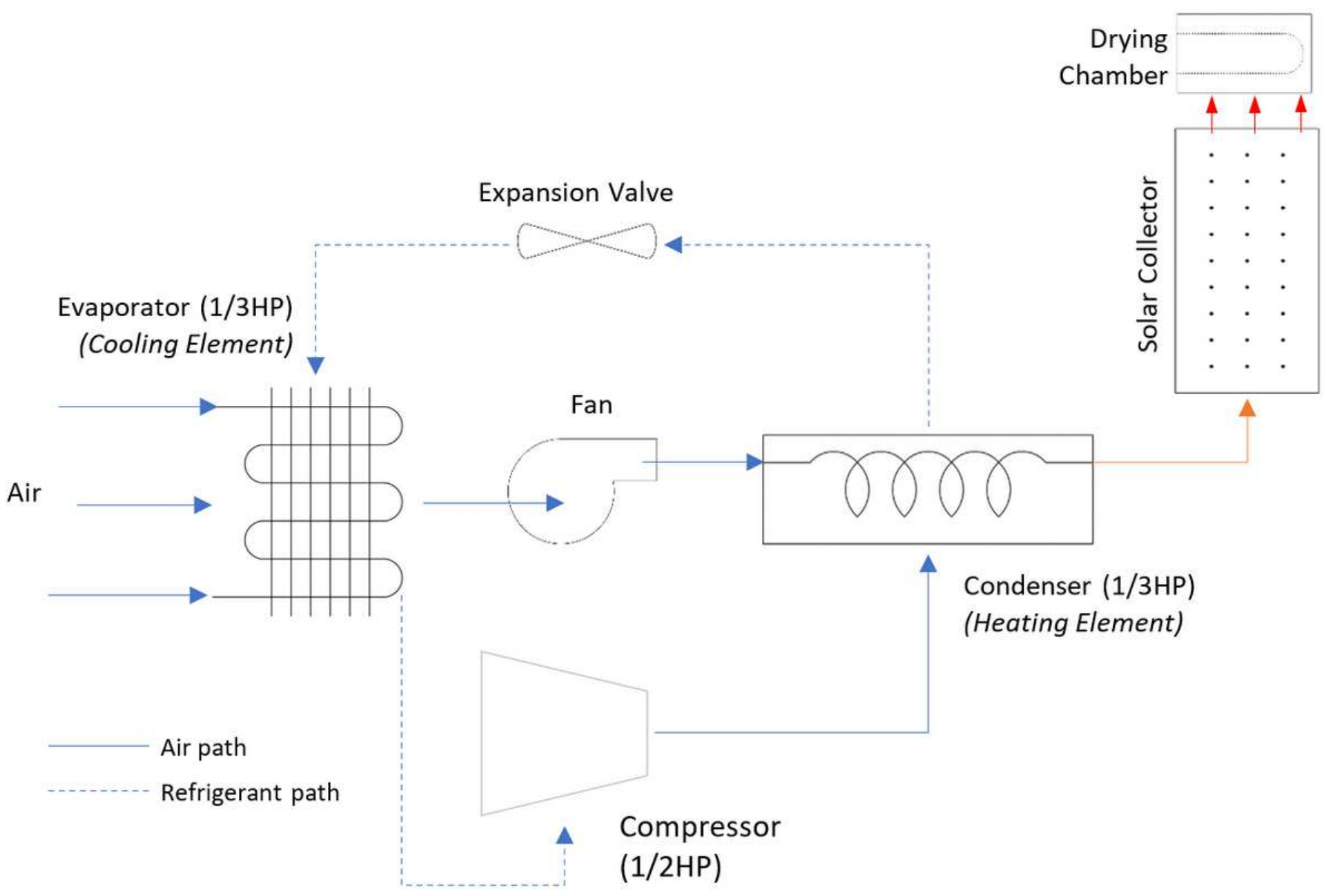

Figure 2

Schematic diagram of heat pump solar dryer
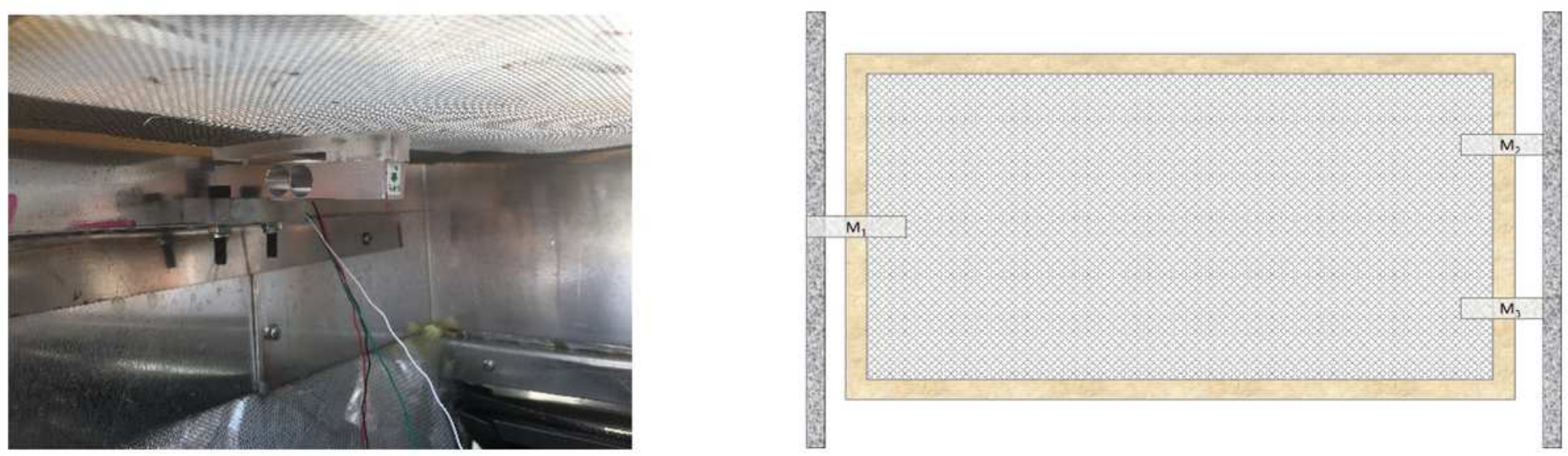

Figure 3

The placement of tray and load cells on a rack 


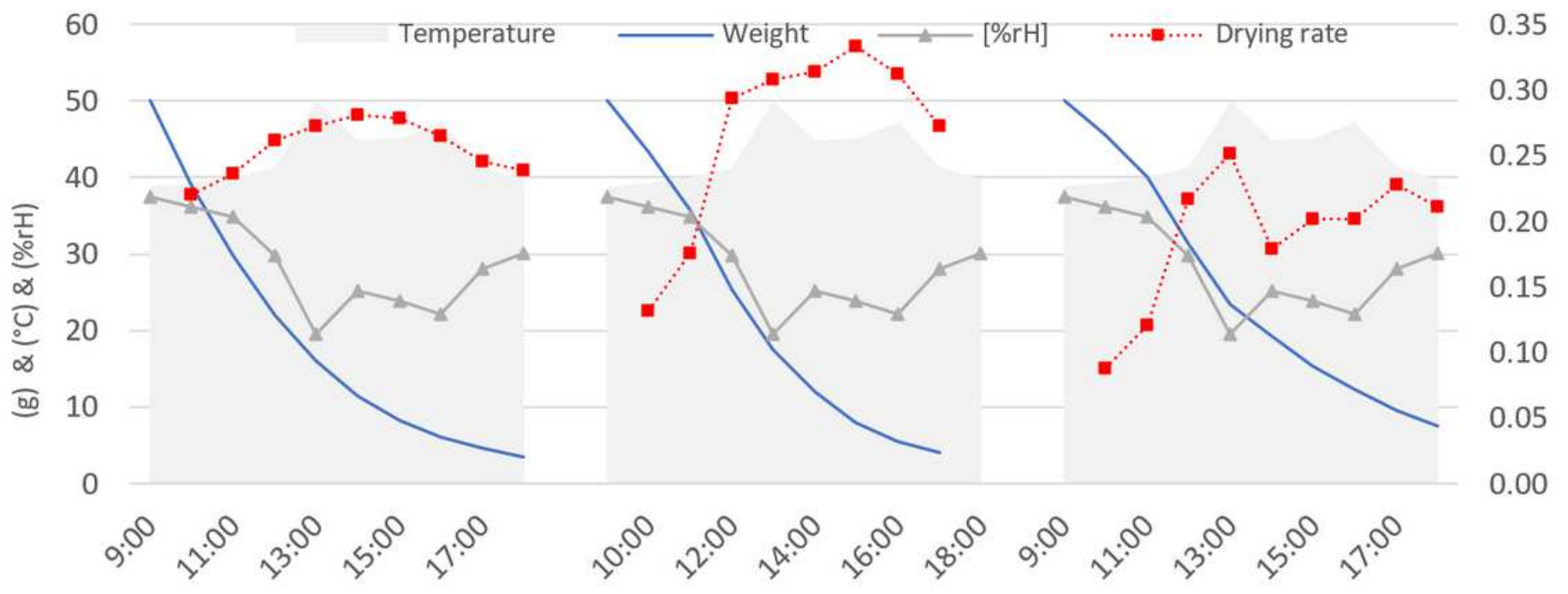

\section{Figure 4}

Relation between drying rate, temperature and relative humidity of drying chamber and drying time for $0.5 \mathrm{~cm}(\mathrm{~T} 1), 1 \mathrm{~cm}(\mathrm{~T} 2)$, and half (T4) sliced mushroom in NCD, respectively

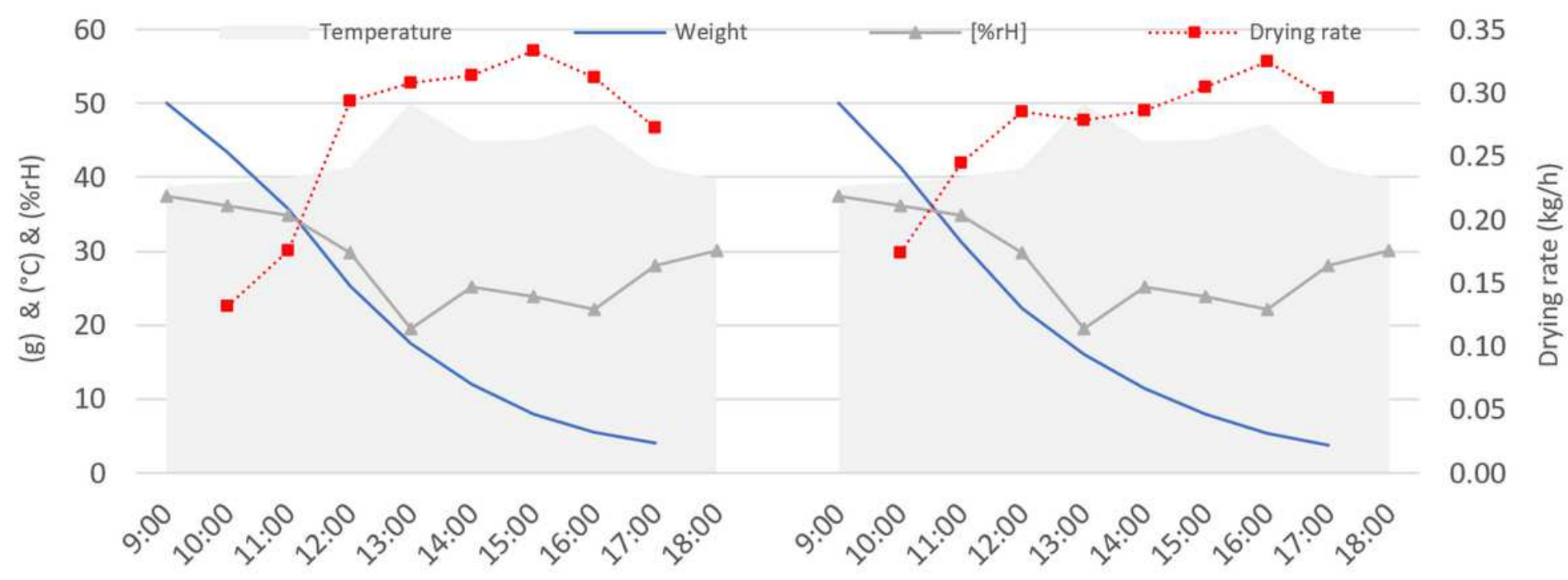

\section{Figure 5}

Relation between drying rate, temperature and relative humidity of drying chamber and drying time for $0.5 \mathrm{~cm}(\mathrm{~T} 1), 1 \mathrm{~cm}(\mathrm{~T} 2)$, and half (T4) sliced mushroom in NCD, respectively 


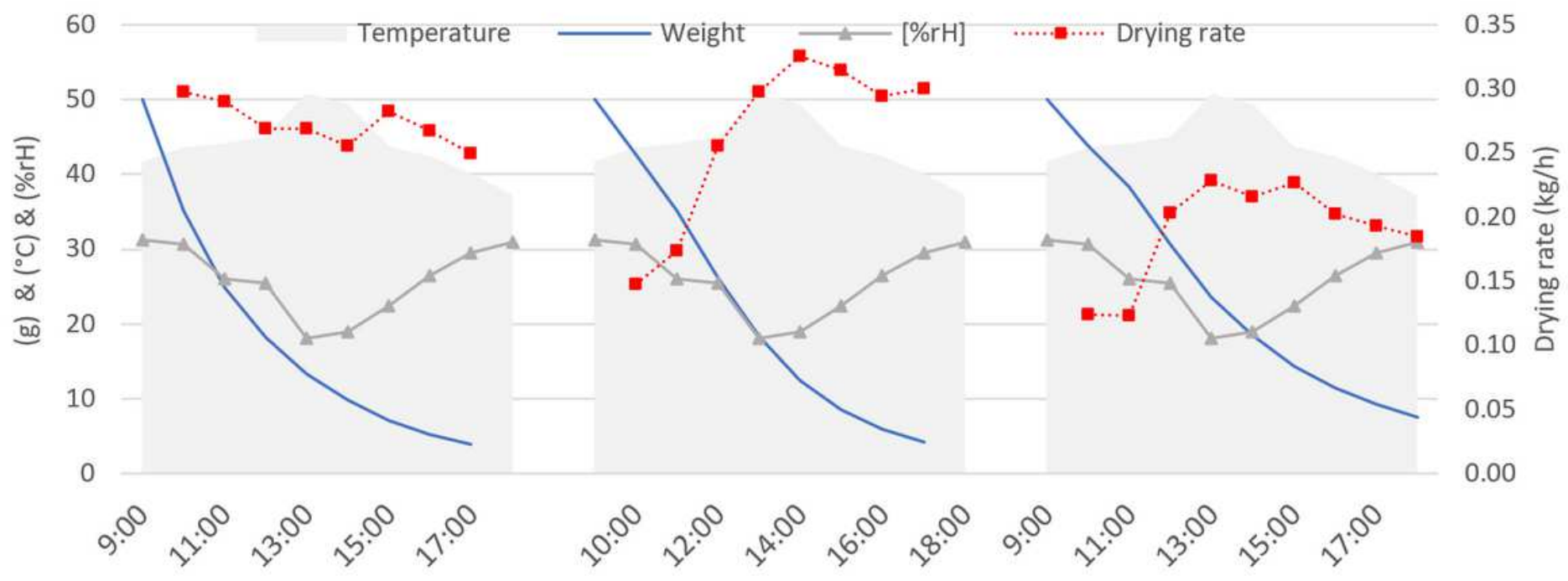

Figure 6

Relation between drying rate, temperature and relative humidity of drying chamber and drying time for $0.5 \mathrm{~cm}(\mathrm{~T} 1), 1 \mathrm{~cm}(\mathrm{~T} 2)$, and half (T4) sliced mushroom in NCD, respectively

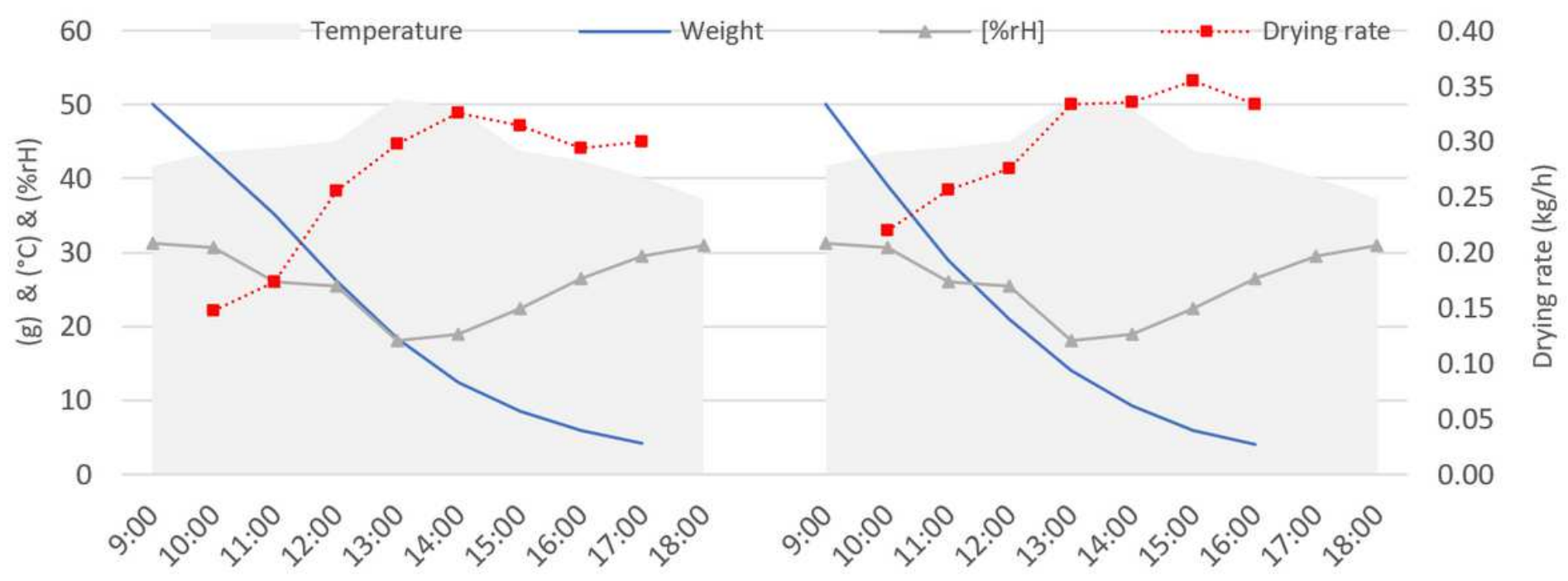

Figure 7

Relation between drying rate, temperature and relative humidity of drying chamber and drying time for non-pretreated (T6) and pre-treated (T7) mushroom, respectively 


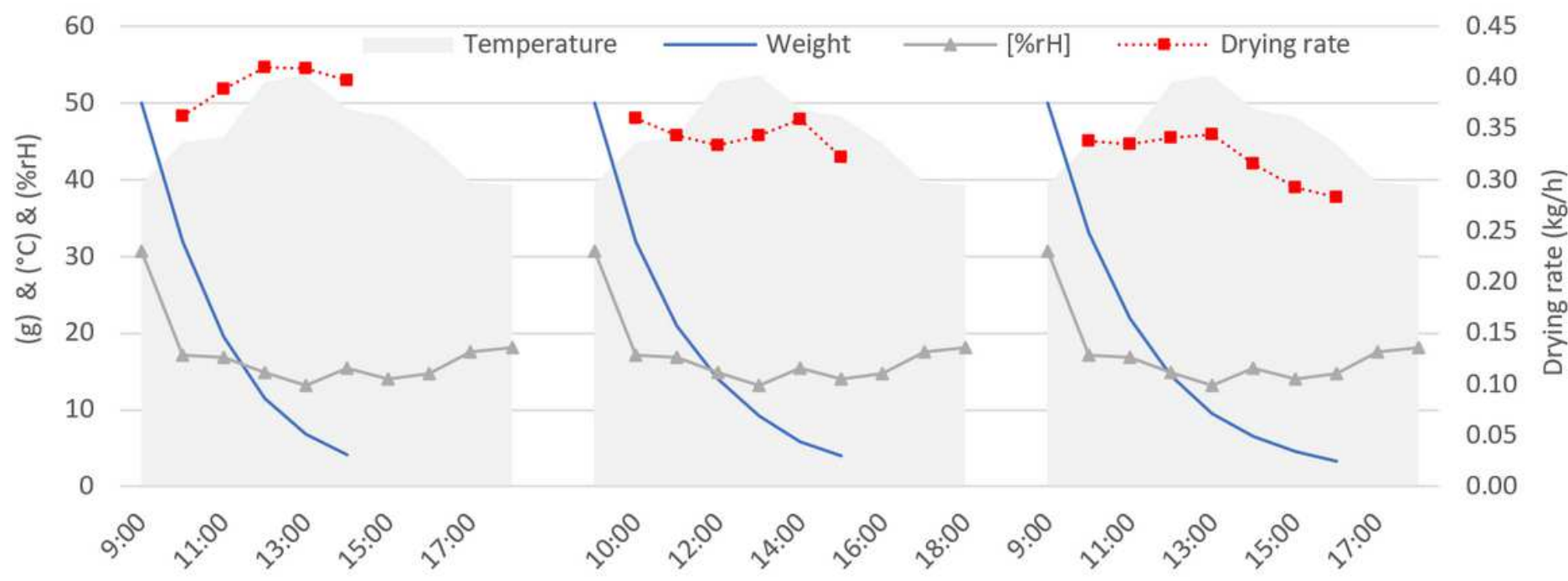

\section{Figure 8}

Relation between drying rate, temperature and relative humidity of drying chamber and drying time for $0.5 \mathrm{~cm}(\mathrm{~T} 9), 1 \mathrm{~cm}(\mathrm{~T} 10)$, and half (T12) mushroom in HPD, respectively

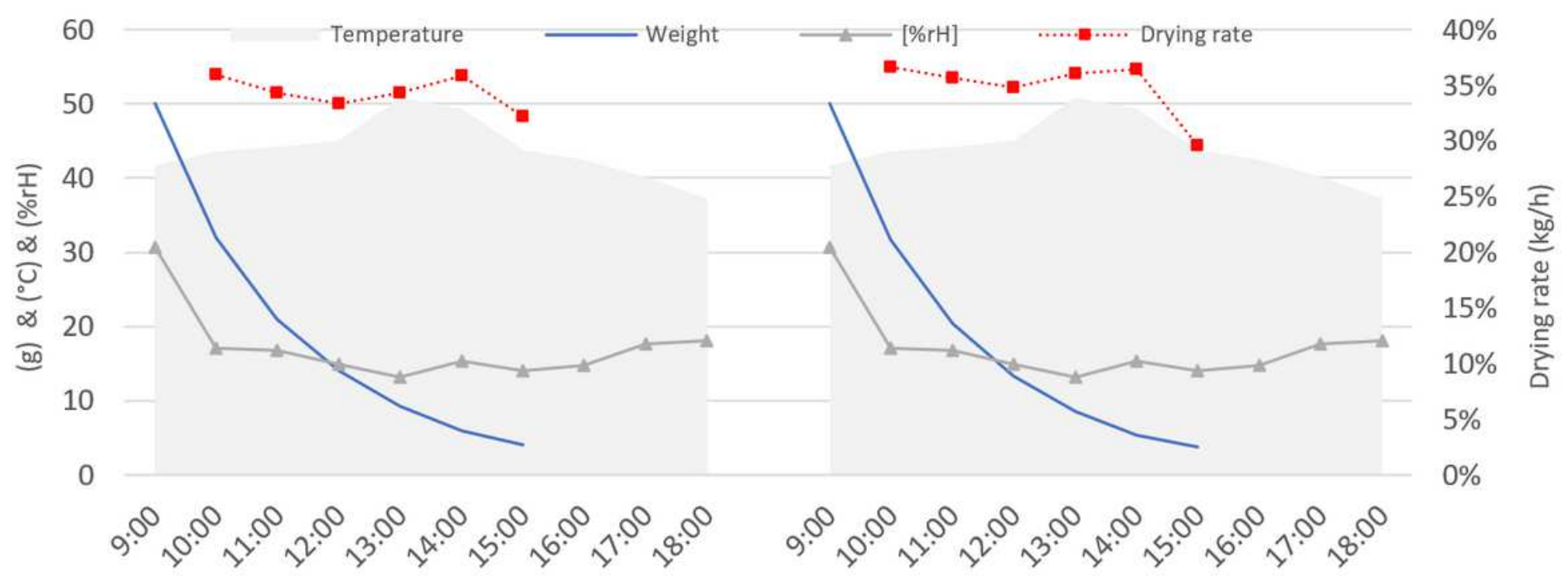

\section{Figure 9}

Relation between drying rate, temperature and relative humidity of drying chamber and drying time for $0.5 \mathrm{~cm}(\mathrm{~T} 9), 1 \mathrm{~cm}$ (T10), and half (T12) mushroom in HPD, respectively 


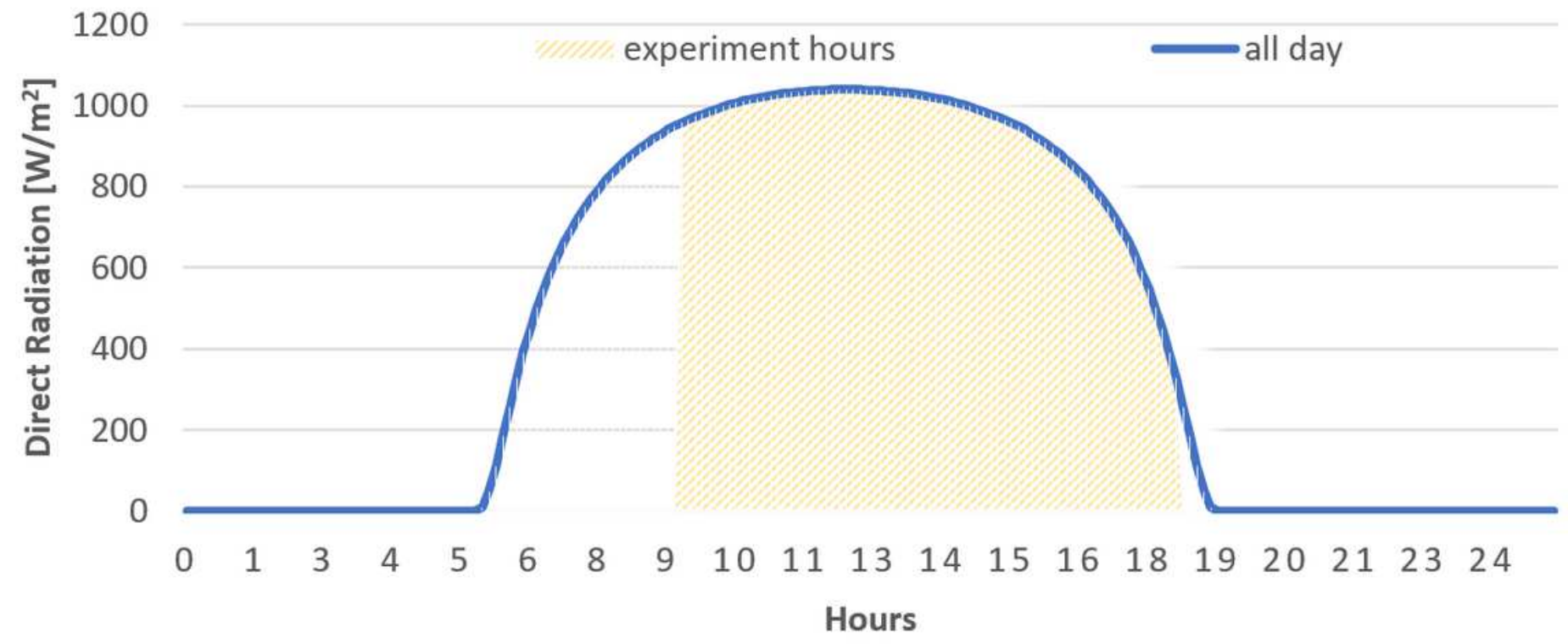

Figure 10

The intensity of direct radiation in $\mathrm{W} / \mathrm{m}^{2}$ throughout the day (18th August 2020) and experiment hours

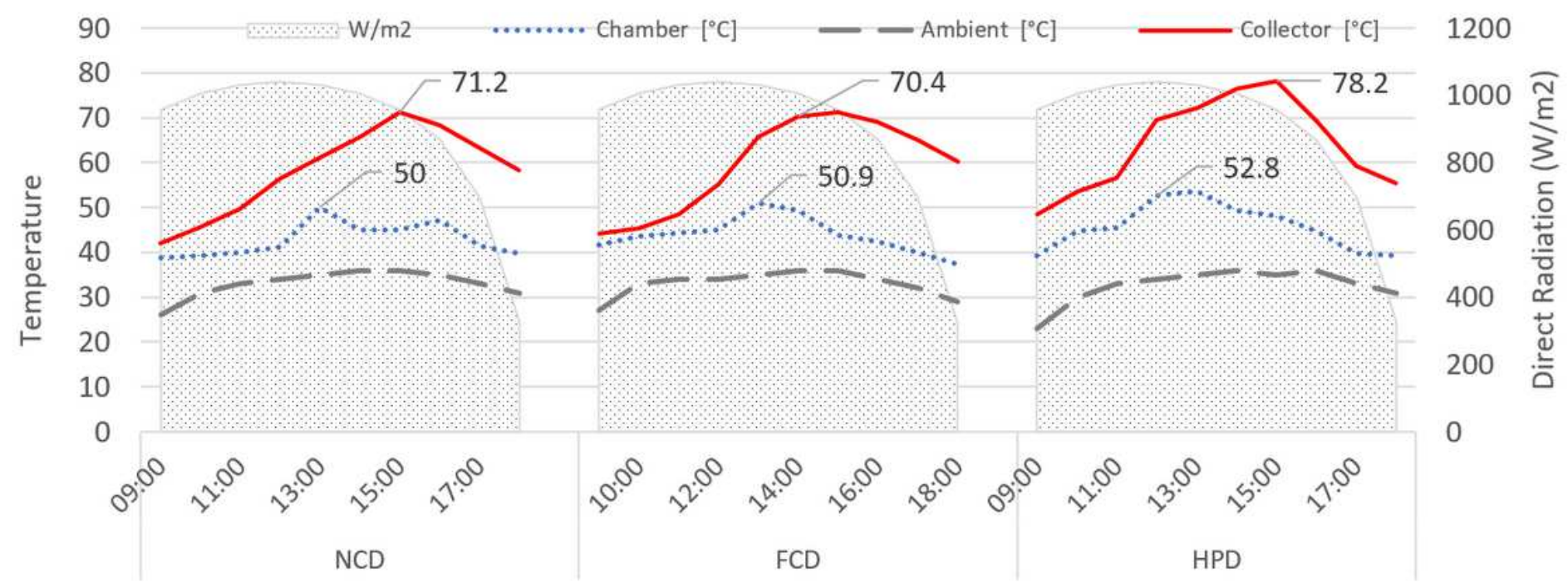

\section{Figure 11}

The hourly variation of temperature and solar radiation for all dryers 


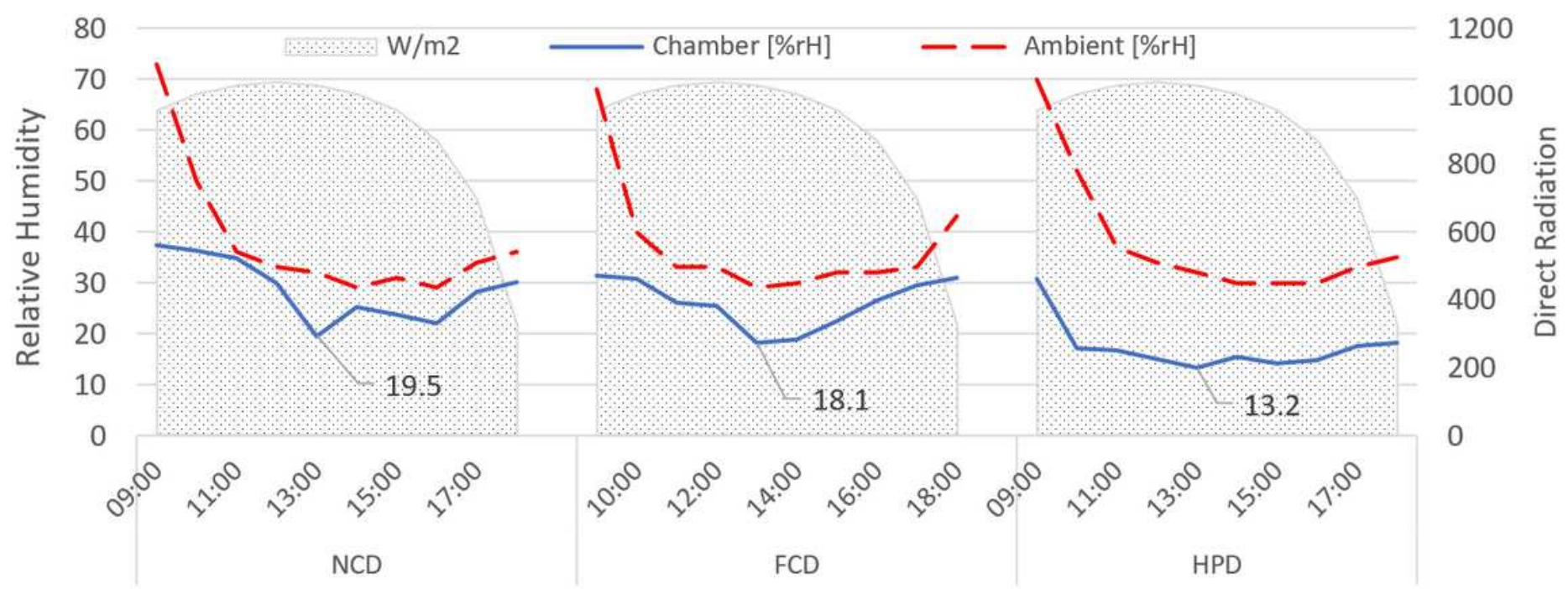

Figure 12

The hourly variation of relative humidity and solar radiation for all dryers

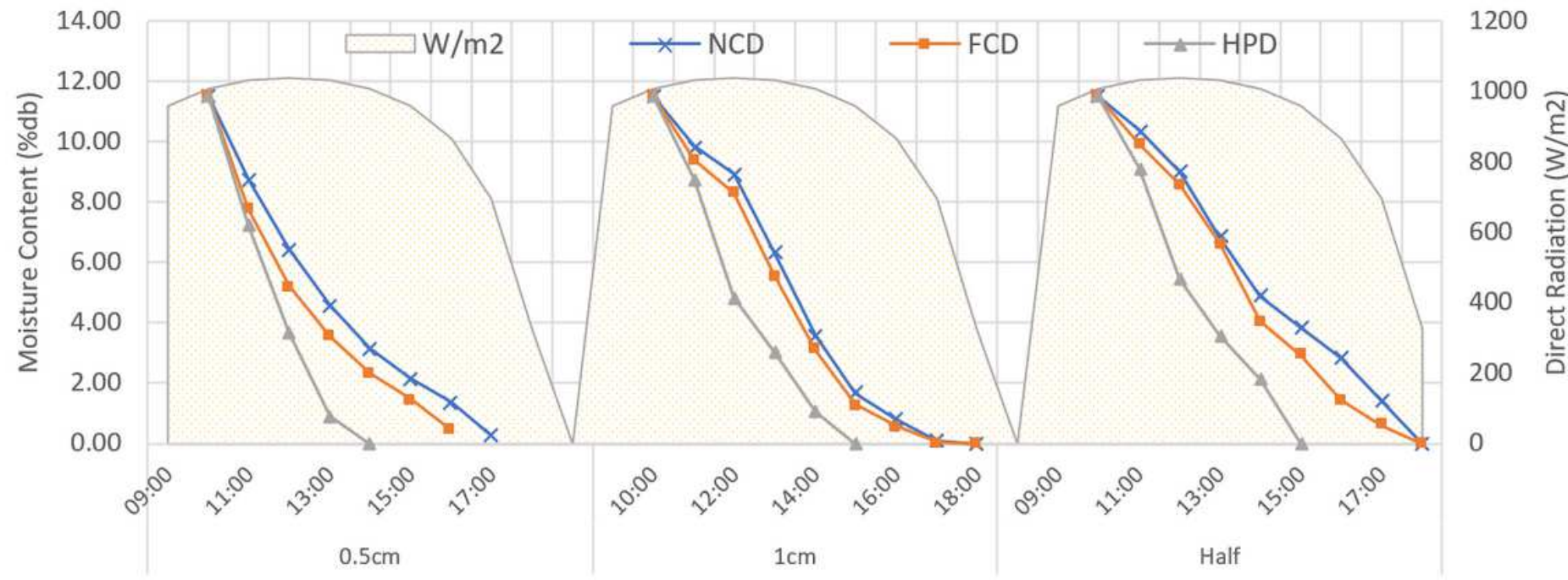

Figure 13

The variation of dry basis moisture content of mushroom in the NCD, FCD and HPD (T2, T6, and T10, respectively) with drying time in hours and direct radiation 


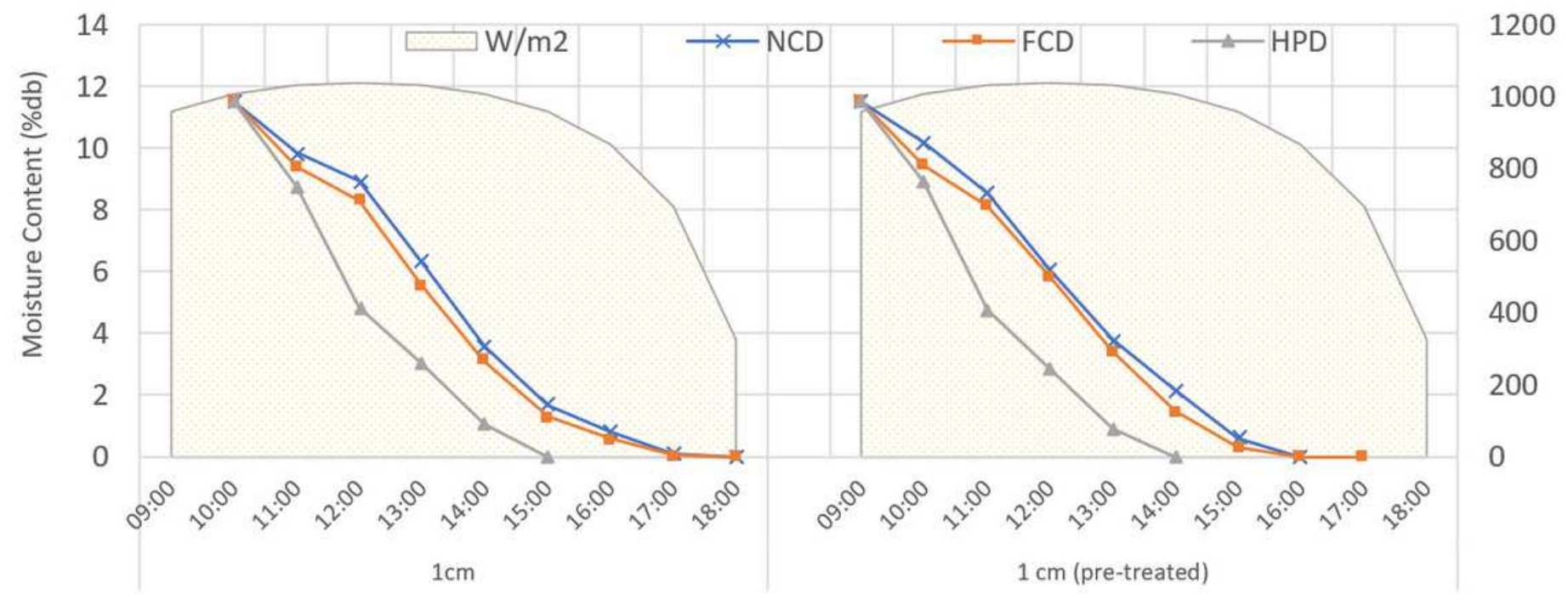

\section{Figure 14}

The variation of dry basis moisture content of mushroom in the NCD, FCD and HPD (T3, T7, and T11, respectively) with drying time in hours and direct radiation

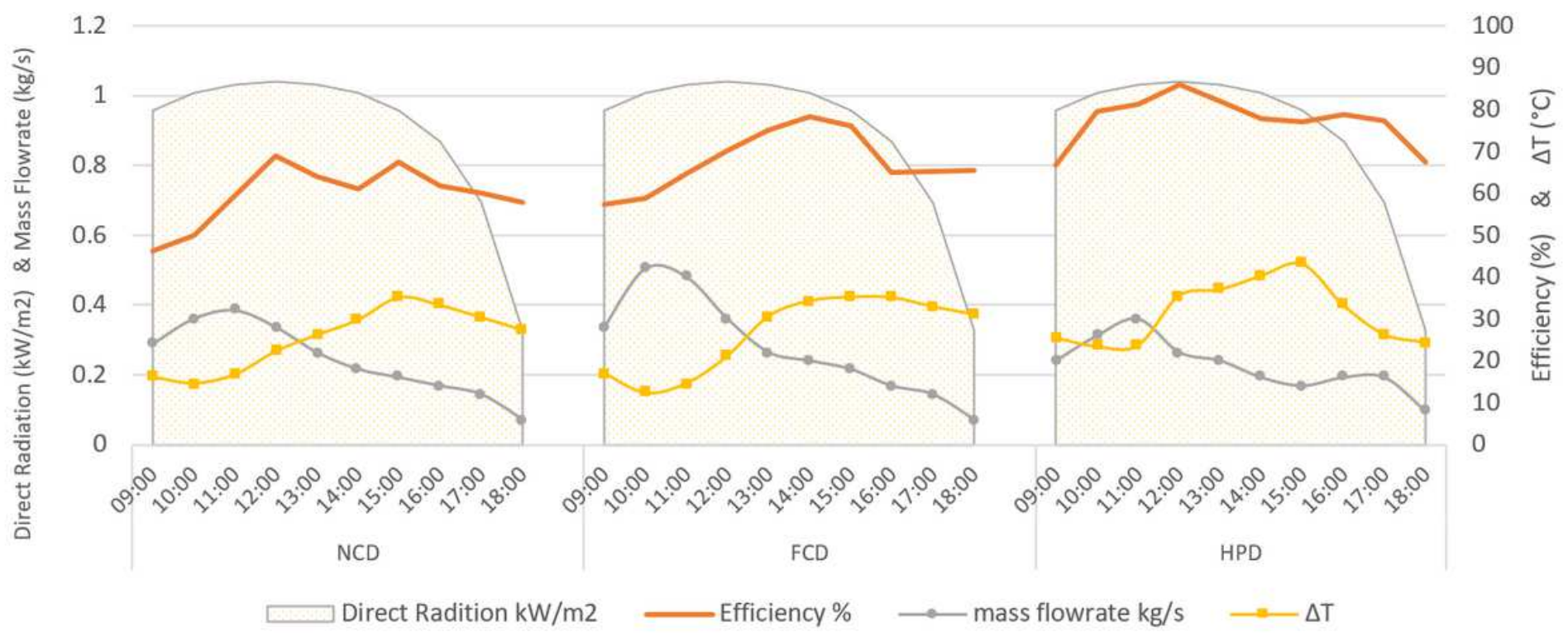

Figure 15

The efficiency of collectors for NCD, FCD and HPD with corresponding drying time and direct radiation 